\title{
DIVERSITY, ABUNDANCE AND SIZE STRUCTURE OF FISHES AND INVERTEBRATES CAPTURED BY AN INTERTIDAL FISHING WEIR AT BRAMBER, MINAS BASIN, NOVA SCOTIA
}

\author{
MICHAEL J. DADSWELL ${ }^{1}$, AARON D. SPARES ${ }^{1}$, \\ ERICA PORTER ${ }^{2}$ AND DARREN PORTER ${ }^{2}$ \\ ${ }^{1}$ Department of Biology, Acadia University, \\ Wolfville, NS B4P 2 R6 \\ ${ }^{2}$ Marine Institute of Natural and Academic Science, \\ Avonport, NS
}

\begin{abstract}
Capturing fish using a weir or trap on the intertidal flats of the Bay of Fundy was developed by native Mi'kamaq who later taught the method to the European settlers. Between 1800-1910 fish weirs were a significant part of the important American shad fishery in the inner Bay of Fundy before the collapse of the northwest Atlantic population from pollution and damming of major spawning rivers in the United States. Weirs remain an important segment of the Minas Basin fisheries but now the largest commercial catches consist of Atlantic herring, gaspereau and flounders. Studies on the fishes captured in Minas Basin weirs were published in 1852, 1924, 1984 and 2014, but all lacked a sampling intensity which would fully describe the diversity, abundance and size structure of the catch. An intertidal weir at Bramber, Minas Basin was surveyed during April-July, 2017 where catches were examined at each low tide. The weir was constructed on the intertidal flat during early April after Minas Basin cleared of drift ice. During the study period mean daily tide range was $10.46 \mathrm{~m}$ with a maximum spring tide range of $13.72 \mathrm{~m}$. A total of eight neap and eight spring tide cycles were observed. Daily water temperature of Minas Basin was $8.0 \mathrm{C}^{\circ}$ during late May and increased to a maximum of $21.4 \mathrm{C}^{\circ}$ in late July. Fish and invertebrate collections began on April 10 and continued daily until July 22 when water temperatures in the trap became too warm for by-catch species to survive $\left(+25 \mathrm{C}^{\circ}\right)$. During the study period an estimated total of 674,402 fishes consisting of 45 species were captured and of these 57,950 were measured. The most abundant fishes observed were gaspereau (alewife and blueback herring 51.9\%), rainbow smelt (13.9\%), Atlantic herring (13.0\%) and tomcod (10.1\%). Other commonly captured fishes were American shad, skate (little and winter), winter flounder, windowpane flounder, striped

* Author to whom correspondence should be addressed: mike.dadswell@acadiau.ca
\end{abstract}


bass, mackerel and Atlantic sturgeon. A total of 18,511 invertebrates were captured and counted. The most abundant were long-fin squid (13.8\%) and crustaceans (rock crab, lady crab; 84.0\%).

Keywords: Bay of Fundy; Canada; Clupeidae; commercial fishing; temperatures; tides

\section{INTRODUCTION}

The fisheries of the inner Bay of Fundy and Minas Basin began with the native Mi'kmaq. They used intertidal weirs and spears to capture fishes for sustenance and trade (Gordon 1993). The dominant species taken were sturgeon, herring, gaspereau, shad, salmon, smelt, and tomcod, but they probably also utilized any other fishes they captured. When the Acadian settlers arrived during the early 1600's the Mi'kmaq taught them how to use weirs to catch fish for their survival and the methods were passed onto other settlers who followed later. By the 1800 's the fishery developed into a major commercial enterprise with exports of American shad to the United States of up to 1,000 metric tonnes $(t)$ annually (Perley 1852; Dadswell et al. 1984a).

Intertidal fishing weirs are constructed during spring of spruce stakes driven into the intertidal substrate in a V-shape with the tip of the $\mathrm{V}$ pointed offshore and then covered with interwoven brush or nets (Gordon 1993). At high tide the weir is underwater. As the tide ebbs fishes are guided into the weir trap which is then fished at low water. In the past horse drawn wagons were used to land the catch. Some weirs in Minas Basin were serviced with horses until the 1980's but all are now are fished with trucks or all-terrain vehicles (Dadswell; pers. obs.).

Intertidal weirs have remained one of the main fisheries methods used in Minas Basin to the present day. During the 1800's hundreds of weirs lined the shores of Minas Basin (Perley 1852). The American shad captured were so important to the economy of Nova Scotia that a Special Act of the Nova Scotia Legislature was passed in 1840 for its regulation, one of the first in Canada. Today weirs are few and the dominant catch is gaspereau (the collective French name for alewife and blueback herring) which are mainly used as bait in the lobster fishery. Other species commonly captured now or in the past are Atlantic sturgeon, Atlantic salmon, Atlantic herring, striped bass, winter flounder, Atlantic mackerel and longfin squid (Dadswell et al.1984b).

Biological studies on the fishes captured in Bay of Fundy intertidal weirs began with Perley (1852) who surveyed weirs in Cumberland 
and Minas Basins. Liem (1924) conducted in depth weir surveys from 1919-1923 for the Royal Commission established to determine the cause of the collapse of the American shad fishery in the inner Bay of Fundy. His findings concerning the diversity and abundance of fishes caught in weirs were confirmed by Dadswell et al. (1984b) in a study of Minas Basin weirs during 1982-1983. A total of 44 fish species were identified from weir catches during these two studies.

The Fundy Ocean Research Centre for Energy (FORCE) recently conducted a study in which Minas Basin fishing weirs were monitored from April-August, 2013 (Baker et al. 2014). Sampling was conducted once weekly during daytime low tides at weirs near Five Islands and Bramber, Nova Scotia (Fig 1) and during day and night tides for commercial species and weight at the Bramber weir from mid-July to the first week of August. Their study documented 28 species of fish overall and 24 species at the Bramber site and addressed abundance and size of selected fishes during the monitored period. Sampling, however, was not intense enough to document the

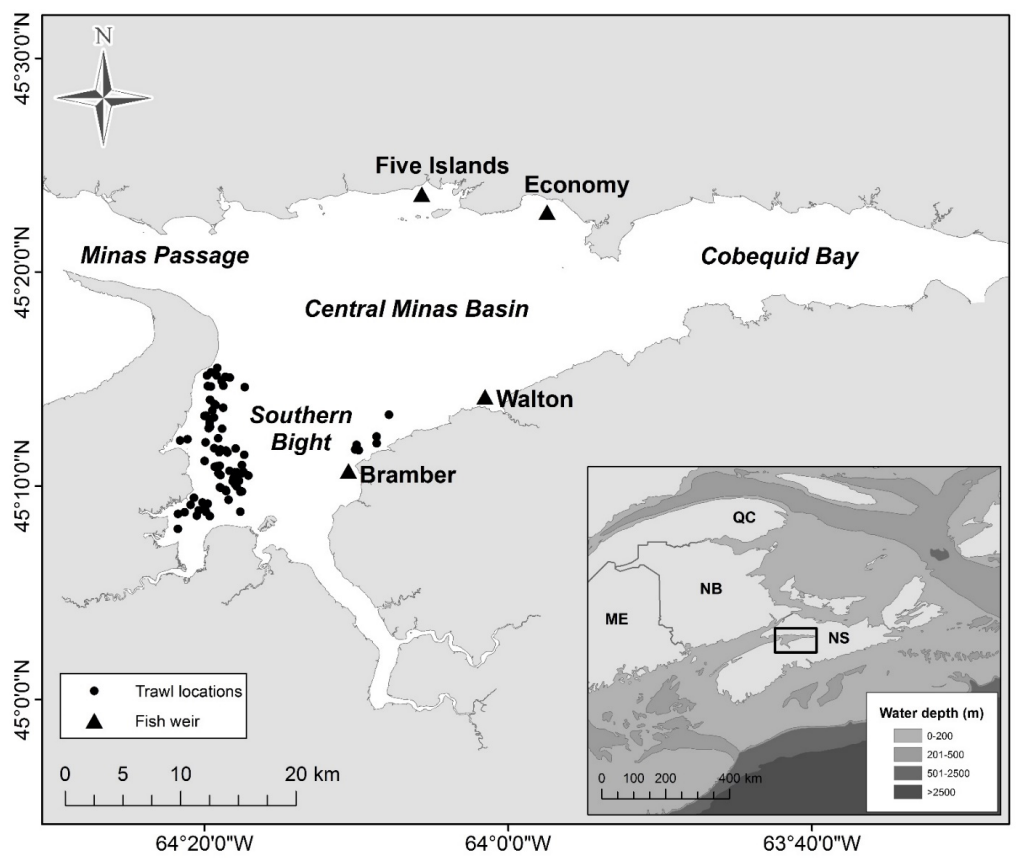

Fig 1 Minas Basin, Nova Scotia, depicting sites of some present and former intertidal fish weirs. Trawl locations depicted were part of another study on the fishes of Minas Basin (Wehrell 2005). 
potential total diversity, abundance and size structure of fishes captured. As part of the final report FORCE stated: 'intertidal weirs are useful sampling platforms for assessing general patterns in the presence and abundance of fishes in the Minas Basin and can strengthen on-going environmental monitoring near tidal energy development sites'. Unfortunately, this statement could not be supported by a study that only sampled the catch one day a week during daylight tides. Consequently, on June 14, 2016, in a memo posted to their website, the Department of Fisheries and Oceans (DFO) recommended that further evaluation of the potential use of intertidal weirs to gather additional seasonal baseline information on fish assemblages and habitat use in the vicinity of the tidal energy projects should be undertaken.

In 2017, the commercial fishers of Minas Basin, in conjunction with Big Moon Power Canada agreed to undertake a joint project to monitor diversity, seasonal abundance trends and size structure of resident and migratory fishes. The objective was to establish a comprehensive baseline for fish assemblages in the Minas Basin, as well as an updated species index. This study was conducted as a fisher would work their weir with sampling conducted during every low tide night and day from April to July. Fishers had criticized earlier weir studies based on the fact that sampling was not intense enough to accurately demonstrate the actual diversity, abundance and size structure of Minas Basin fishes in weir catches and this was justified by DFO's 2016 critique of the FORCE study.

As the selected sampling station, the Bramber weir was designed to create an easily replicated model for scientific purposes. Technical aspects of the weir were modified to keep the maximum number of controllable variables constant. To conduct this study with maximum efficiency, a team was assembled, consisting of experienced fishers, students and scientists. The study, by approach and design, is anticipated to be a relationship-builder that will combine the existing knowledge from local, traditional and academic groups, with cooperative industries.

\section{METHODS}

\section{Environmental Sampling}

A daily record of moon cycle and tide range was maintained from the Department of Fisheries and Oceans website 


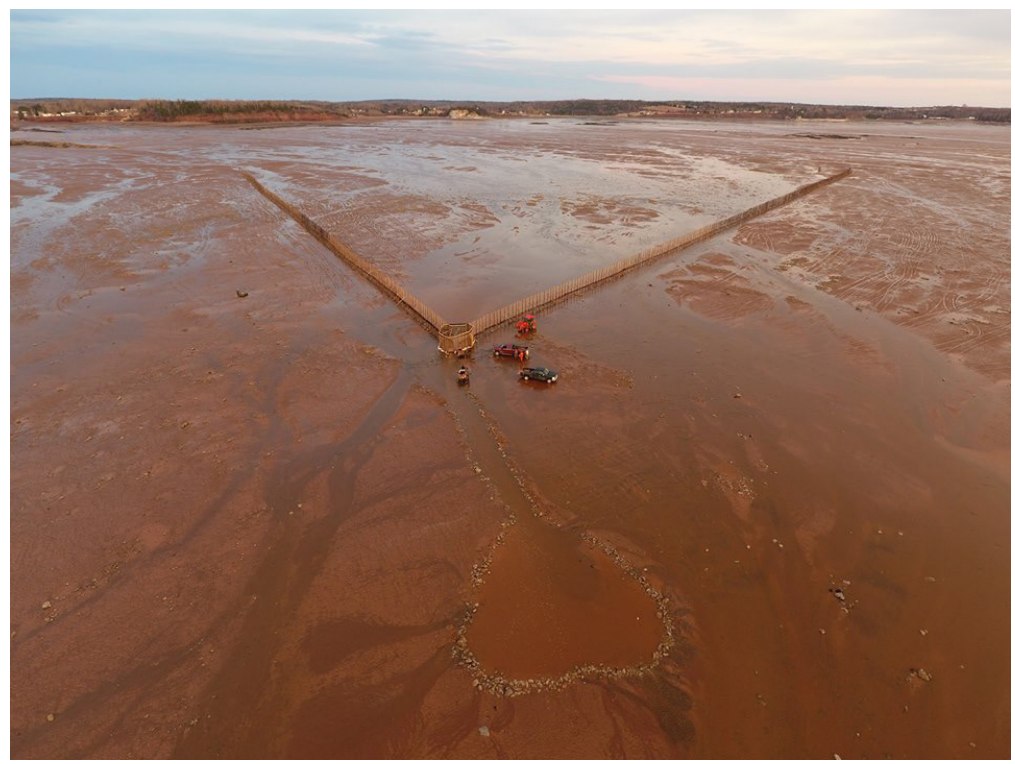

Fig 2 The Bramber intertidal fish weir used during the 2017 study at low tide in Minas Basin. The V-shape is described by the weir wings which lead the fish into the trap at the near end during ebb tide. Fishers and their vehicles are clustered around the trap. The channel and heart-shaped structure in the lower portion of the picture is a live holding pond into which non-commercial fishes and invertebrates prohibited for take were released so they could escape unharmed.

(www.dfo-mpo.gc.ca/index-eng.htm/waterlevels). Three temperature data loggers were deployed at the weir. One on the inshore (short) wing, one on the offshore (long wing) and one in the trap (Fig 2). Temperatures were logged every 15 minutes and averaged on each hour from May 26 until July 31, 2017.

\section{Weir Survey}

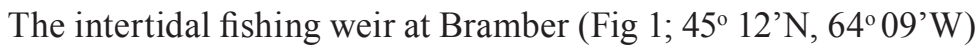
was constructed of spruce poles driven into the intertidal substrate and covered with $2.5 \mathrm{~cm}$ square mesh nylon at the trap and progressively larger mesh (max. $4.0 \mathrm{~cm}$ square) to the wing ends to facilitate release of smaller fishes (Fig 2). The weir walls were $2.2 \mathrm{~m}$ in height until half way to the trap when they were increased to $3 \mathrm{~m}$. The wings were approximately $700 \mathrm{~m}$ in length. The $\mathrm{V}$-shaped weir walls ended in a trap $3 \mathrm{~m}$ in height that was also roofed to prevent fish from leaving the trap at high tide and birds from preying on the captured fishes 
(Fig 2). At low tide the trap was emptied in stages through a sluice gate to maintain water in the trap and alleviate stress on bycatch species. Fish and invertebrates were netted at the trap sluice gate and transferred onto sorting tables for counting and measuring. Large fishes such as sturgeon and striped bass were removed from the trap by hand or dip net and taken directly to the live holding pond seaward of the trap after counting, measuring and/or tagging (Fig 2). Fish that were reluctant to leave the trap (flounders, eels, etc.) were captured by hand or with a dip net and retained as commercial catch or transferred to the holding pond after processing.

Commercial catch was sorted into wharf boxes and a subsample taken for measurement. By catch was counted and all or a subsample measured. If the commercial and/or by-catch species represented less than $\sim 60$ individuals, all were measured. Total catch of commercial species which were too abundant to count directly was estimated by determining an average weight in the catch for the fish concerned on that tide and dividing it into the total weight of landed catch of that species caught during that low tide.

The weir survey consisted of twice daily sampling of commercial catch and bycatch from April 10 until July 22 when the weir was closed because rising temperatures were endangering the survival of bycatch species. Fishes were measured for fork length $\left(\mathrm{L}_{\mathrm{F}}\right)$ and/or total length $\left(\mathrm{L}_{\mathrm{T}}\right)$ depending on the species. Species with forked tails (sturgeon, herring, gaspereau, shad, smelt and striped bass) were measured for $\mathrm{L}_{\mathrm{F}}$. Fishes with rounded tails (eel, tomcod, flounder, etc.) were measured for $\mathrm{L}_{\mathrm{T}}$. Commercial species were landed to sell and by-catch species were released into the live pond to await the rising tide (Fig 2). A portion of the captured Atlantic sturgeon, striped bass, and skate were tagged with external Floy dart tags provided by researchers studying these fishes.

\section{RESULTS AND DISCUSSION}

\section{Environmental Characteristics}

Minas Basin has the largest tide range in the world ( $\max 17+\mathrm{m}$ ). The characteristic result from such large tides is that Minas Basin has extensive intertidal flats which range from 1-5 km wide when exposed at low tide (Parker et al. 2007). The intertidal flats consist of sand, silt, mud and bedrock with little exposed rock and a very 
low abundance of intertidal seaweed because of winter ice scour. The intertidal flat at Bramber was a mixture of sand and mud with rocks and boulders of various sizes strewn over the surface (Fig 2). The rocks are the result of ice rafting during winter depositing the rocks during the spring melt (Sanderson and Redden 2015).

Mean daily range at the Bramber weir during the study period was $10.46 \mathrm{~m}$ with the maximum spring tide range of $13.72 \mathrm{~m}$ on April 28, 2017. A total of eight neap and eight spring tide cycles were observed during weir operation with the largest tides occurring in April and May. Daily water temperature of Minas Basin at the Bramber site was $8.0 \mathrm{C}^{\circ}$ during late May when data loggers were deployed and increased to a maximum of $21.4 \mathrm{C}^{\circ}$ on July 14 . Trap temperatures during low tide were similar to the ambient Basin temperature until July when solar insolation caused trap temperatures to increase quickly during the low-tide fishing period, often becoming $>25.0 \mathrm{C}^{\circ}$.

The summer fishing period during 2017 was significantly warmer than during the 2013 FORCE study. During 2013 summer surface water temperature never exceeded $19 \mathrm{C}^{\circ}$ and the Bramber weir remained operational until mid-August (Baker et al. 2014).

\section{Weir Catches}

An estimated total of 674,402 fishes were captured by the Bramber weir during April 10 to July 22, 2017. The catch consisted of 45 species of fish (Table 1). Gaspereau, consisting of blueback herring and alewife, were the most abundant fish representing an estimated 350,343 of those captured or $51.9 \%$ of the total catch. Rainbow smelt were the second most abundant catch (13.9\%) followed by Atlantic herring at $13.0 \%$. An estimated 68,212 tomcod were captured (10.1\%) and the three abundant species of flounder made up $7.3 \%$ of the total catch. Other important contributors to the catch were American shad $(1.0 \%)$, hakes $(1.0 \%)$ and skates $(0.4 \%)$. Other species were rare and often only one specimen was captured during the entire fishing season (spotted hake, striped searobin, etc.). A total of 57,950 fishes were measured.

The fish community captured in Minas Basin weirs can be characterized into four assemblages. There was an assemblage of mainly smaller fish species that live, reproduce in and occupy the Basin year around. This grouping consists of tomcod, rainbow smelt, Atlantic silversides, smooth flounder, windowpane flounder, mummichog, skates, striped bass, sea raven and sticklebacks (Dadswell et al. 1984b). A second 
Table 1 Fishes captured in the Bramber intertidal fish weir during 2017. Species were counted as a group because they were difficult to separate taxonomically on site: ${ }^{* 1}$ - skate; ${ }^{* 2}$ - gaspereau; ${ }^{* 3}$ - hake.

\begin{tabular}{|c|c|c|c|}
\hline Common name & Genus and Species & Catch & $\%$ Total \\
\hline Sea lamprey & Petromyzon marinus & 4 & - \\
\hline Spiny dogfish shark & Squalus acanthias & 10 & - \\
\hline Little skate, Winter skate*1 & Leucoraja erinacea, L. ocellata & 2,874 & 0.41 \\
\hline Atlantic sturgeon & Acipenser oxyrinchus & 247 & 0.03 \\
\hline American eel & Anguilla rostrata & 44 & - \\
\hline American shad & Alosa sapidissima & 7,176 & 1.06 \\
\hline Alewife, Blueback herring*2 & A. pseudoharengus, A. aestivalis & $350,343^{\#}$ & 51.95 \\
\hline Atlantic herring & Clupea harengus & $87,587^{\#}$ & 12.98 \\
\hline Atlantic menhaden & Brevoortia tyrannus & 1 & - \\
\hline Atlantic salmon & Salmo salar & 6 & - \\
\hline Brown trout & Salmo trutta & 9 & - \\
\hline Brook trout & Salvelinus fontinalis & 1 & - \\
\hline Rainbow smelt & Osmerus mordax & $93,976^{\#}$ & 13.94 \\
\hline Three-spine stickleback & Gasterosteus aculeatus & 4 & - \\
\hline Monkfish & Lophius americanus & 4 & - \\
\hline Atlantic cod & Gadus morhua & 6 & - \\
\hline Tomcod & Microgadus tomcod & $68,212^{\#}$ & 10.11 \\
\hline Haddock & Melanogrammus aeglefinus & 6 & - \\
\hline Silver Hake & Merluccius bilinearis & 384 & - \\
\hline White hake, Red hake*3 & Urophycis tenuis, U. chuss & 7,214 & 1.06 \\
\hline Spotted hake & Urophycis regia & 1 & - \\
\hline Longfin hake & Urophycis chesteri & 1 & - \\
\hline Pollack & Pollachius virens & 1 & - \\
\hline Mummichog & Fundulus heteroclitus & 2 & - \\
\hline Atlantic silversides & Menidia menidia & 2,063 & 0.31 \\
\hline Northern pipefish & Syngnathus fuscus & 7 & - \\
\hline Striped bass & Morone saxatilis & 1,388 & 0.20 \\
\hline White perch & Morone americana & 12 & - \\
\hline Cunner & Tautogolabus adsperus & 51 & - \\
\hline Sea raven & Hemitripterus americanus & 643 & 0.09 \\
\hline Shorthorn sculpin & Myoxocephalus scorpius & 4 & - \\
\hline Longhorn sculpin & Myoxocephalus octodecemspinous & 705 & 0.10 \\
\hline Ocean pout & Macrozoarces americana & 1 & - \\
\hline Rock gunnel & Pholis gunnellus & 5 & - \\
\hline Butterfish & Peprilus triacanthus & 536 & 0.08 \\
\hline Atlantic mackerel & Scomber scombrus & 1,820 & 0.27 \\
\hline Striped searobin & Prionotus evolans & 1 & - \\
\hline Summer flounder & Paralichthyes dentatus & 2 & - \\
\hline Winter flounder & Pseudopleuronectes americanus & $24,214^{\#}$ & 3.59 \\
\hline Smooth flounder & Liopsetta putnami & 5,841 & 0.86 \\
\hline Windowpane & Scophthalmus aquosus & 18,860 & 2.82 \\
\hline \multirow[t]{2}{*}{ Halibut } & Hippoglossus hippoglossus & 2 & - \\
\hline & Total catch & $674,402^{\#}$ & \\
\hline
\end{tabular}

\footnotetext{
\# count estimated
} 
assemblage consists of summer migrants into Minas Basin many of which are diadromous species that reproduce in the streams around the Basin. This group consisted of sea lamprey, spiny dogfish shark, Atlantic sturgeon, American eel, Atlantic herring, American shad, gaspereau, Atlantic salmon, Atlantic mackerel and winter flounder. They are the dominant community that supports the commercial fishery (Dadswell et al. 1984b). A cold-water assemblage enters the Basin in early spring and departs when water temperatures surpass $10 \mathrm{C}^{\circ}$. Atlantic cod, haddock, pollock and halibut are representatives (Bleakney and McAllister 1973). Rare coldwater and/or offshore species among this grouping that were caught at Bramber during 2017 were ocean pout, spotted hake and longfin hake. The final assemblage consists of warm-water migrants that arrive from the south when Basin water temperatures reached their annual maximum (Scott and Scott 1988). During the summer of 2017 this group was represented by butterfish, summer flounder and striped searobin.

A total of 18,511 large invertebrates captured were counted (Table 2). The most abundant invertebrate was the lady crab which

Table 2 Large invertebrates captured at the Bramber weir during the summer of 2017.

\begin{tabular}{|c|c|c|c|}
\hline Common name & Taxon & Catch & $\%$ Total \\
\hline & Cnidaria & & \\
\hline \multirow[t]{2}{*}{ Lion's Mane Jellyfish } & Cyanea capillata & 128 & 0.07 \\
\hline & Ctenopora & & \\
\hline Sea Gooseberry & Pleurobranchia pileus & rare & - \\
\hline \multirow{3}{*}{ Longfin squid } & Mollusca & 2,560 & 13.8 \\
\hline & Doryteuthis pealei & & \\
\hline & Arthropoda & & \\
\hline Shrimp & Dichelopandalus leptocerus & 1 & - \\
\hline Sand shrimp & Crangon septemspinosa & uncounted & $\begin{array}{c}\text { very } \\
\text { abundant }\end{array}$ \\
\hline American lobster & Homarus americanus & 36 & 0.02 \\
\hline Rock crab & Cancer irroratus & 1,626 & 8.77 \\
\hline Green crab & Carcinus maenas & 158 & 0.08 \\
\hline Lady crab & Ovalipes ocellatus & 13,997 & 75.57 \\
\hline Toad crabs & Hyas araneus & uncounted & $\begin{array}{c}\text { very } \\
\text { abundant }\end{array}$ \\
\hline \multirow{4}{*}{ Hermit crabs } & Libinia emarginata & 5 & - \\
\hline & Pagurus acadianus & uncounted & abundant \\
\hline & Pagurus longicarpus & uncounted & rare \\
\hline & Total catch counted & 18,511 & \\
\hline
\end{tabular}


made up $75.6 \%$ of the total counted catch. Longfin squid, the only invertebrate that contributed to the commercial catch, made up $13.8 \%$ of the counted catch followed by rock crabs at $8.8 \%$. Other invertebrates were either rare, small, very abundant and/or difficult to identify and were not counted.

\section{CHARACTERISTICS OF CAPTURED FISHES}

Data collected from fishes captured during April-July, 2017 consisted of number and length of species captured during each low tide. We summarize the fishes captured below.

\section{Sea lamprey}

The total catch of sea lamprey in the Bramber weir during 2017 was only four individuals (Table 1). Low catch was probably an interaction between morphology, biology and migration of this species. Lamprey morphology is eel-like rendering them capable of escaping through all but the smallest net mesh sizes. Sea lamprey are an anadromous species which remains offshore as juveniles feeding on the blood of other fishes (Scott and Scott 1988). Adults return to their natal stream during spring (May-July) to spawn and then die. No lamprey were captured during the FORCE study (Baker et al. 2014).

\section{Spiny dogfish shark}

A total of ten spiny dogfish shark were captured during late May, 2017. All were adults ranging in length from $750-940 \mathrm{~mm} \mathrm{~L}_{\mathrm{T}}$.

This species is both demersal and pelagic but apparently remains offshore and away from the intertidal zone resulting in low weir catches (Moore 1998). Also the dogfish stock has been at a low ebb for the past decade (Campana et al. 2008) and are no longer abundant in Minas Basin as they were during the 1980's (Dadswell et al. 1984b).

Other sharks taken in Minas Basin weirs include great white shark and sand tiger shark. A great white shark was captured in an Economy weir during 2011 and the same weir captured a sand tiger shark in 2017 (Fig 1; W. Linkletter, pers. comm.).

\section{Skates}

Two species of skate were captured during 2017, little skate and winter skate (Table 1). They were considered together because they are difficult to identify at the weir (Whidden 2015). A total of 2,874 

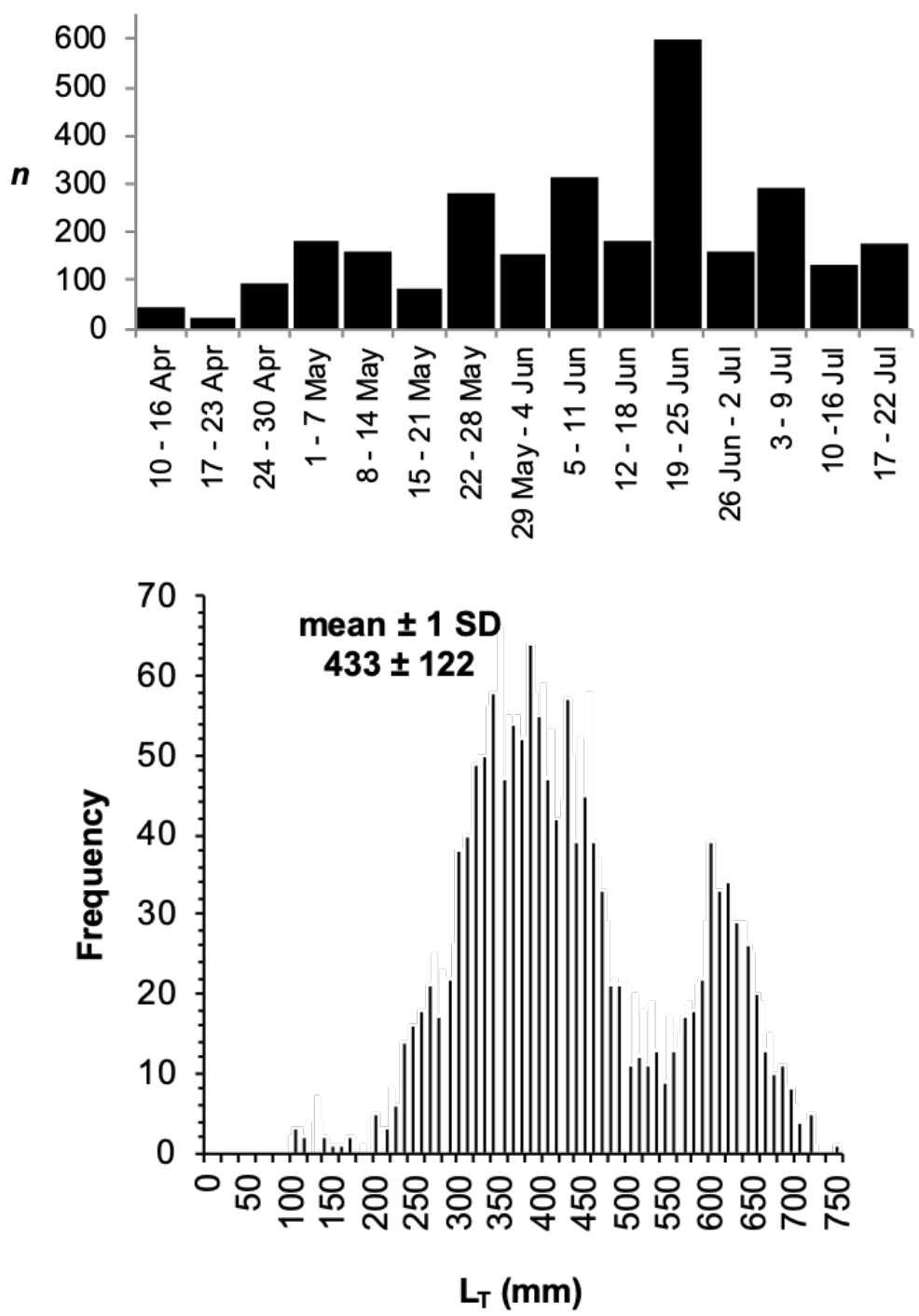

Fig 3 (Top) Weekly catches (n) of skate captured in the Bramber weir from April 10-July 22, 2017; (Bottom) Total length $(\mathrm{mm})$ frequency of skate captured in the Bramber weir during April 10 to July 22, 2017. Lengths are grouped in $5 \mathrm{~mm}$ bins.

skate were captured. Catches were greatest during late May to early July. Their weekly abundance in the weir catches ranged from 15600 individuals (Fig 3) which was similar to the abundance found by Whidden (2015) during 2012-2014. 
Length frequency distribution of skate ranged from 100-750 $\mathrm{mm} \mathrm{L}_{\mathrm{T}}$ (Fig 3). There was an obvious bimodal distribution in lengths (peaks at 350-400 and 600-650 $\mathrm{L}_{\mathrm{T}}$ ) perhaps caused by considering the two species together. Winter skate adults are larger than little skate adults (Whidden 2015). The overall mean length \pm 1 S.D. of captured skates was $433 \pm 122 \mathrm{~mm} \mathrm{~L}_{\mathrm{T}}$.

\section{American eel}

A total of 44 American eel were captured during 2017 (Table 1). Individuals were yellow eel of 500-600 $\mathrm{mm} \mathrm{L}_{\mathrm{T}}$. This catch was probably an underestimate of eel abundance at Bramber because eels are exceptionally adapt at finding escape routes from nets and traps because of their small diameter and mucus covered skin (Scott and Scott 1988). No American eel were reported captured during the FORCE study (Baker et al. 2014).

\section{Atlantic sturgeon}

A total of 247 Atlantic sturgeon were captured from late April until the weir was closed (Fig 4). Weekly catches during this period varied between one to 50 sturgeons. Maximum daily catches ranged from 2-3 fish during April-May to 6-12 sturgeon in June-July. The largest catches came during late June to July as the annual aggregation of feeding sturgeon in Minas Basin migrated into the Southern Bight (Dadswell et al. 2016).

Atlantic sturgeon were the largest fish species captured by the Bramber weir during 2017. Sturgeon ranged from $52.3 \mathrm{~cm}$ to $239.5 \mathrm{~cm} \mathrm{~L}_{\mathrm{T}}$ (Fig 4). The mean length $\pm 1 \mathrm{SD}$ of the catch was 147.4 $\pm 31.3 \mathrm{~cm} \mathrm{~L}_{\mathrm{T}}$ which was consistent with the annual mean length of the summer aggregation during previous years (Baker et al. 2014; Dadswell et al. 2016). The major portion of the annual feeding aggregation which runs through Minas Basin each summer are juvenile Atlantic sturgeon of 10-25 years of age and 110-170 $\mathrm{cm} \mathrm{L}_{\mathrm{T}}$ from the Saint John R., NB and the Kennebec R., ME (Wirgin et al. 2012).

Sturgeon feed on the benthic marine invertebrates found in the Minas Basin intertidal flats (McLean et al. 2013). It is during their feeding forays onto the tide flats at high tide that they are captured in the weirs. Atlantic sturgeon have anadromous populations which occur along the east coast of North America from Florida to Quebec and which migrate annually along the Atlantic coast (Dadswell 2006). 

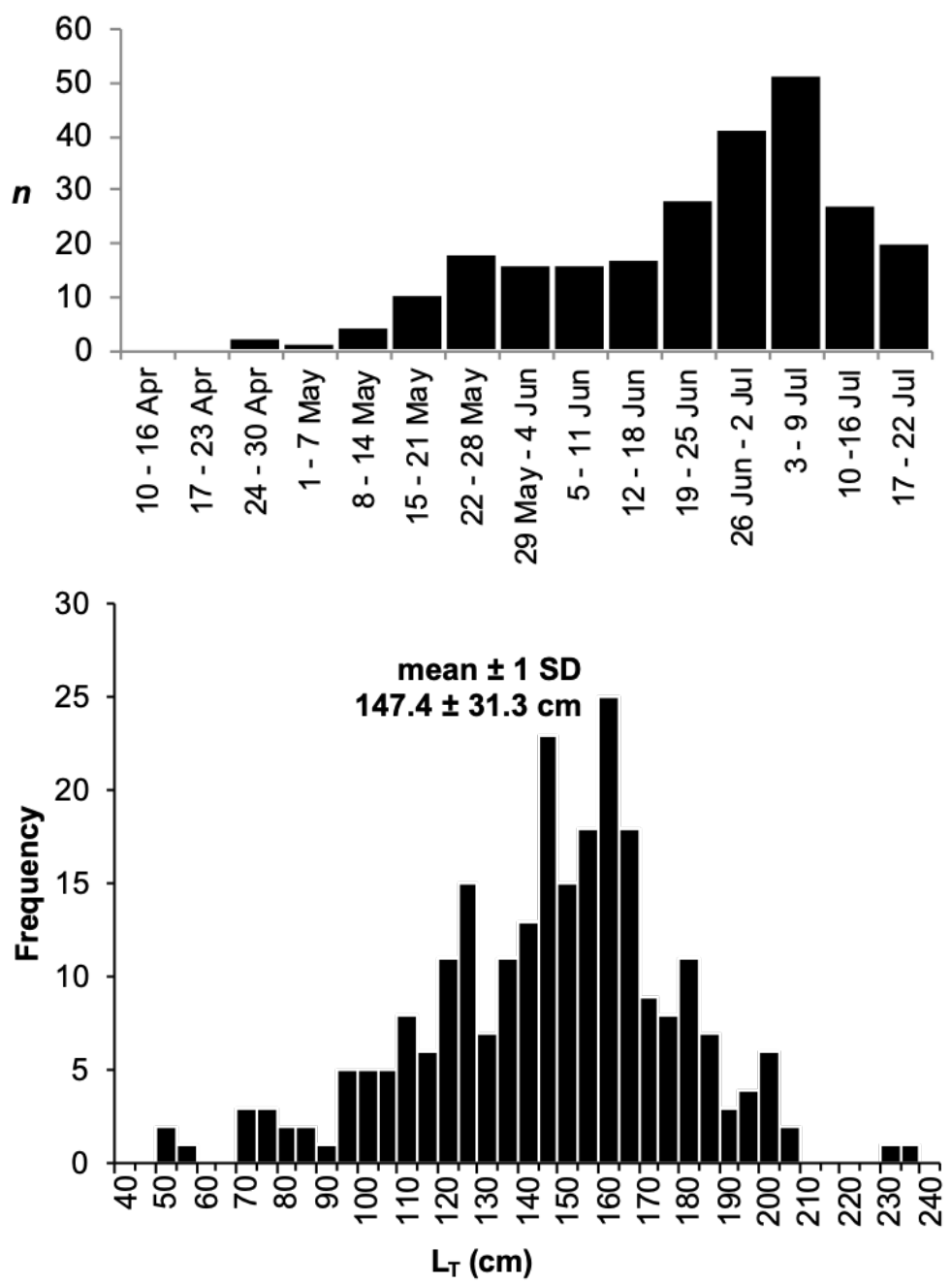

Fig 4 (Top) Weekly catch (n) of Atlantic sturgeon at the Bramber weir during April to July, 2017. Total catch was 251 fish. (Bottom) Fork length (mm) frequency distribution (5-cm bins) of Atlantic sturgeon captured in the Bramber weir April to July, 2017. Unmeasured fork lengths $(n=1)$ were extrapolated based on the following fork to total length relationship $\left(L_{T}=\right.$ $\left.1.1026 L_{F}+37.609 ; r^{2}=0.99 ; n=246\right)$.

Sturgeon tagged in Minas Basin have been captured as far south as New Jersey and north to the Gaspe Peninsula (Dadswell et al. 2016).

Atlantic sturgeon no longer constitute a legal commercial catch in Minas Basin although they were an important component of 
the commercial catch in some Minas Basin weirs in the past. The commercial take of Atlantic sturgeon in marine waters of Canada was closed by DFO in 2002 in order to facilitate the management of the spawning stocks in natal rivers such as the Saint John R., NB (Dadswell et al. 2017).

A total of 74 sturgeon were tagged during 2017 with external, FLOY dart tags supplied by Acadia University and a total of ten recaptures of externally tagged sturgeon were taken in the Bramber weir. Seven of these were from sturgeon tagged in Minas Basin in previous years, two of which were tagged in the Bramber weir during 2013. Three were tagged in previous years by researchers in the Saint John River, NB.

\section{Clupeidae}

A total of five species of the family Clupeidae (herring-like fishes) were captured. These were American shad, alewife, blueback herring, Atlantic herring and menhaden (Table 1). Herring catches were lower than in previous years but gaspereau catches were larger (D. Porter, pers. obs.). Based on the way these pelagic species school it is difficult to conclude if the difference in abundance among years represents a real change in abundance or the chance, random movement of large schools intercepted by the weir.

\section{American shad}

A total of 7,176 American shad were captured from early April until the weir was closed in July (Table 1). Weekly catches varied from a few to 2000 (Fig 5). Largest catches were in July as the annual shad migration through Minas Basin reached the Southern Bight (Fig 1; Dadswell et al. 1984a).

Lengths of captured American shad were from $43 \mathrm{~mm}$ to $652 \mathrm{~mm}$ $\mathrm{L}_{\mathrm{F}}$ (Fig 5) which was similar in range to catches during 2013 (Baker et al. 2014). Smaller shad, in the length range of $100-200 \mathrm{~mm} \mathrm{~L}_{\mathrm{F}}$, were the most common. These were age- 1 shad possibly from the local spawning populations in Minas Basin. Adult shad of 350-550 $\mathrm{mm} \mathrm{L} \mathrm{L}_{\mathrm{F}}$ were the second most common group. These fish were age3 to age-5 and probably consisted of shad from rivers all along the Atlantic coast (Dadswell et al. 1987). Weir catches of adult shad at Bramber during 2017 were low compared to weir catches in Minas Basin during the 1980's (Dadswell et al. 1984a) but similar to catches during 2013 (Baker et al. 2014). 

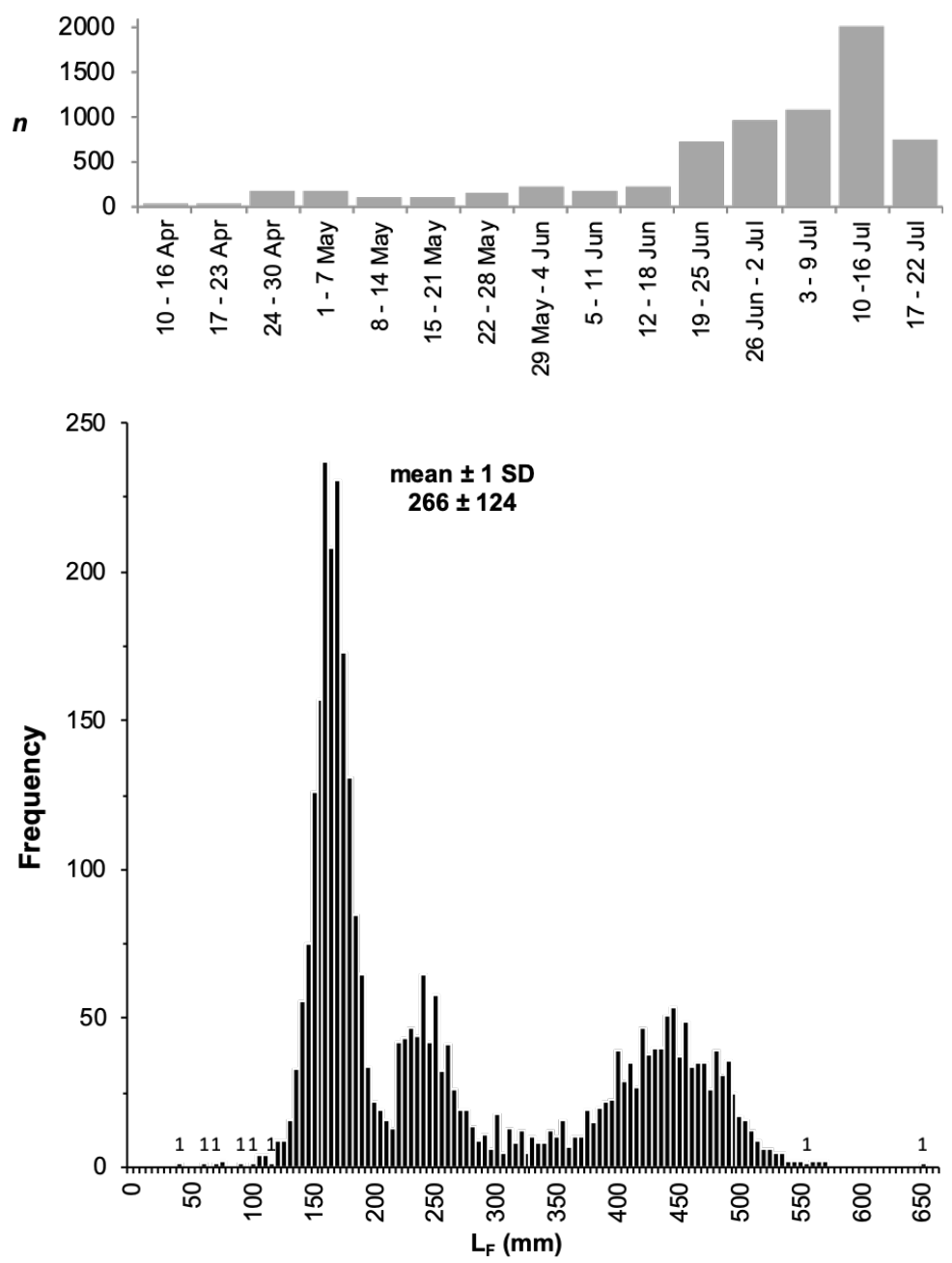

Fig 5 (Top) Weekly catches (n) of American shad captured in the Bramber weir during April to July 2017. Total catch was 7,176 shad. (Bottom) Fork length $(\mathrm{mm})$ frequency of American shad captured at the Bramber weir during April-July, 2017. Lengths are grouped in $5 \mathrm{~mm}$ bins. Ones (1) above $\mathrm{x}$-axis indicate a catch of a single shad in that bin.

Shad are an anadromous, pelagic species which have river spawning populations from Florida to Labrador and migrate annually along the Atlantic coast of North America. Shad tagged in Minas Basin have been captured as far south as Florida and as far north as Labrador (Dadswell et al. 1987). 


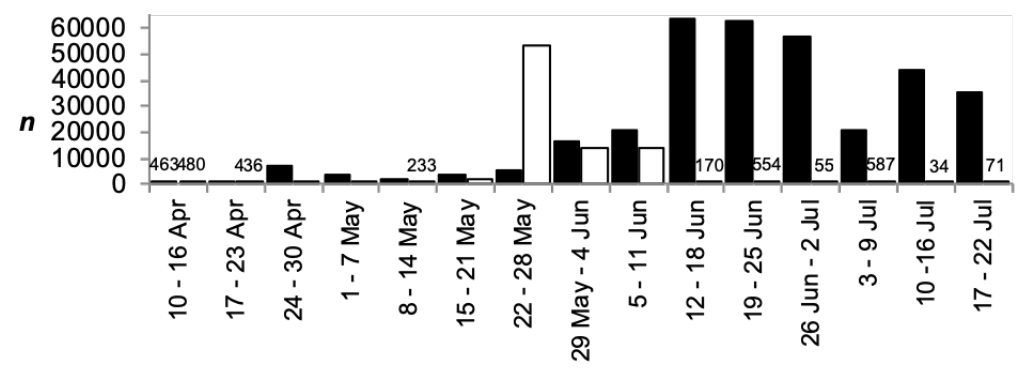

Fig 6 Weekly estimated catches ( $n$ ) of gaspereau (solid bars, $n=350,343$ ) and Atlantic herring (open bars, $n=87,587$ ) captured in the Bramber weir during April to July 2017. Weekly estimated catches of less than 1,000 individuals are indicated with numbers on the $\mathbf{x}$-axis.

\section{Gaspereau}

An estimated total of 350,343 gaspereau (Alosa pseudoharengus and A. aestivalis) were captured during April to July (Table 1). This catch represented $51.9 \%$ of all the fishes examined during 2017 . Weekly catches ranged from 233-60,000 fish and abundance was consistently high throughout the period of weir operation (Fig 6).

The length range of captured gaspereau was $38-282 \mathrm{~mm} \mathrm{~L}_{\mathrm{F}}$ (Fig 7) which represented fish from age-0 to age-3 (Stone 1985). Fish of 200-280 $\mathrm{mm} \mathrm{L}_{\mathrm{F}}$ (age-3) were the most abundant. Age-3 gaspereau were equally represented by males and females. Males were a mean $\pm 1 \mathrm{SD}$ of $241 \pm 19 \mathrm{~mm} \mathrm{~L}_{\mathrm{F}}$; females, $253 \pm 17 \mathrm{~mm} \mathrm{~L}_{\mathrm{F}}$. The lack of larger $\left(+300 \mathrm{~mm} \mathrm{~L}_{\mathrm{F}}\right)$ and older gaspereau (age-4 and age-5) in the catches was probably because mature fish would have been spawning in local streams during April to July (Gibson and Daborn 1997).

Gaspereau are another anadromous, pelagic species which have spawning populations in rivers from Florida to Quebec and migrate annually along the east coast of North America (Scott and Scott 1988). Gaspereau tagged in Minas Basin have been captured as far south as North Carolina (Rulifson et al. 1987).

\section{Atlantic Herring}

An estimated 87,587 Atlantic herring were captured during 2017 which represented $13.0 \%$ of the total weir catch (Table 1). Herring catches were largest from early May to June. Weekly catches ranged from 34-50,000 fish with the highest catches during late May (Fig 6).

Atlantic herring captured during 2017 ranged from 32-350 mm $\mathrm{L}_{\mathrm{F}}$ (Fig 8). Virtually all herring captured were mature fish from 

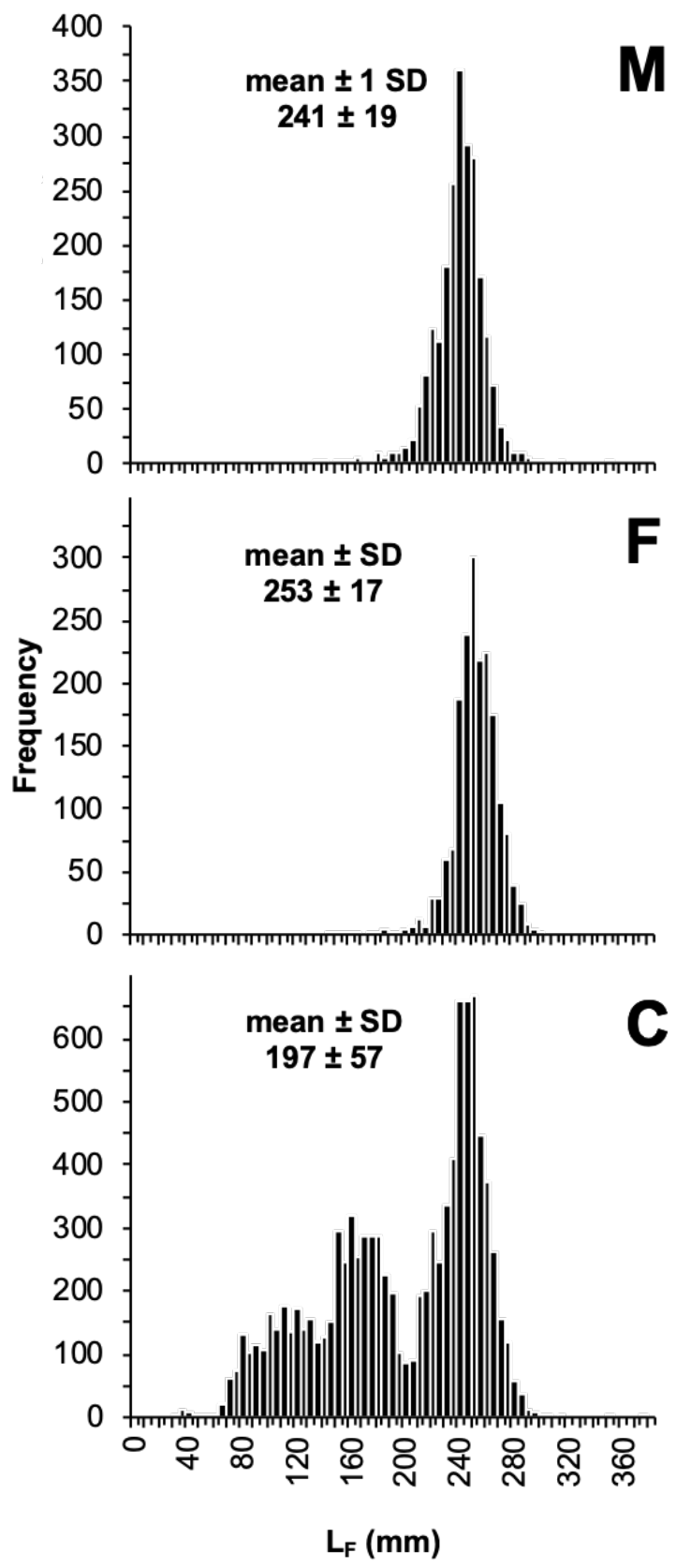

Fig 7. Fork length $(\mathrm{mm})$ frequency of gaspereau captured in the Bramber weir, April-July 2017. Top $(M=$ males $)$, center $(F=$ females $)$, bottom $(C=$ total individuals). Lengths grouped in $5 \mathrm{~mm}$ bins. 

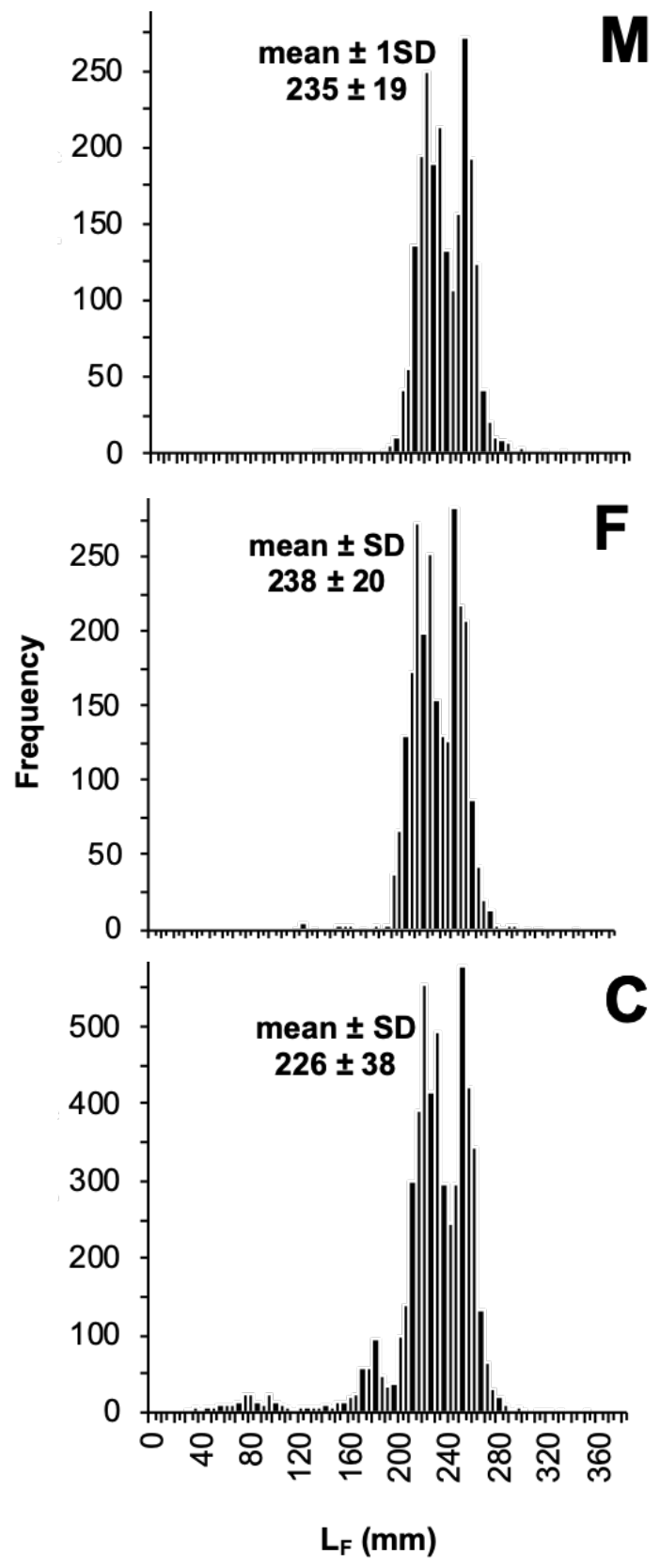

Fig 8 Fork length ( $\mathrm{mm}$, grouped in $5 \mathrm{~mm}$ bins) frequency distribution of Atlantic herring captured in the Bramber weir during April to July, 2017. Top (M) males, middle (F) females, bottom (C), all individuals. 
200-290 $\mathrm{mm} \mathrm{L}_{\mathrm{F}}$. Males averaged $235 \pm 19 \mathrm{mmL}_{\mathrm{F}}$, (range 130-330 $\mathrm{mm} \mathrm{L}_{\mathrm{F}}$, $n=2,185$ ); females, $238 \pm 20 \mathrm{~mm} \mathrm{~L}_{\mathrm{F}}$ (range 124-350 $\mathrm{mm} \mathrm{L}_{\mathrm{F}}, n=2,438$ ).

Minas Basin has a small, spring spawning stock of Atlantic herring estimated at $\sim 100 t$ (Bradford and Iles 1993). They are captured in Minas Basin by weirs and by intertidal set gill nets during their spawning migration through the Basin.

\section{Atlantic menhaden}

Only one Atlantic menhaden was captured in the Bramber weir during 2017 (Table 1). In most years the catch of menhaden is larger (10-100 fish; D. Porter, per. obs.) but they are seldom caught in large numbers in Minas Basin (Dadswell et al. 1984b). A small spawning stock of menhaden exists in Minas Basin that spawns during late June in the vicinity of Burntcoat Head (Dadswell and Rulifson, in press).

\section{Salmonidae}

A total of four species of the Salmonidae (salmon-like fishes) were captured in the Bramber weir during 2017 (Table 1). These included Atlantic salmon (6 individuals), brown trout (9 individuals), brook trout (1 fish) and rainbow smelt. Atlantic salmon were represented by both post-smolts and adults. Brown trout and brook trout were adult fish probably from local streams. Only brook trout were reported captured in the weirs during 2013 (Baker et al. 2014).

\section{Rainbow smelt}

The estimated catch of rainbow smelt during 2017 was 93,976 fish (Table 1). Smelt were abundant throughout the fishing period representing $13.9 \%$ of the total catch with weekly catches ranging from 1000-12,000 fish (Fig 9). Largest catches were in July probably because the anadromous adults were in local streams spawning during April and May (Scott and Scott 1988). Catches of smelt were strongly correlated to daytime tides (Fig 9; $\mathrm{P}<0.05$ ). Daytime catches ranged from 10's to 1000's of individuals whereas nighttime catches seldom exceeded ten fish. This observation was not identified by the 2013 FORCE study (Baker et al. 2014) which sampled only daylight low tides and would have been undocumented without the consistent fishing of every tide during 2017.

Length distribution of rainbow smelt during April-July, 2017 ranged from $32-344 \mathrm{~mm} \mathrm{~L}_{\mathrm{F}}(\mathrm{n}=3,954 ;$ Fig 10). The mean length $\pm 1 \mathrm{SD}$ of the catch was $149 \pm 42 \mathrm{~mm} \mathrm{~L}_{\mathrm{F}}$. Captured smelt ranged from age-1 to 

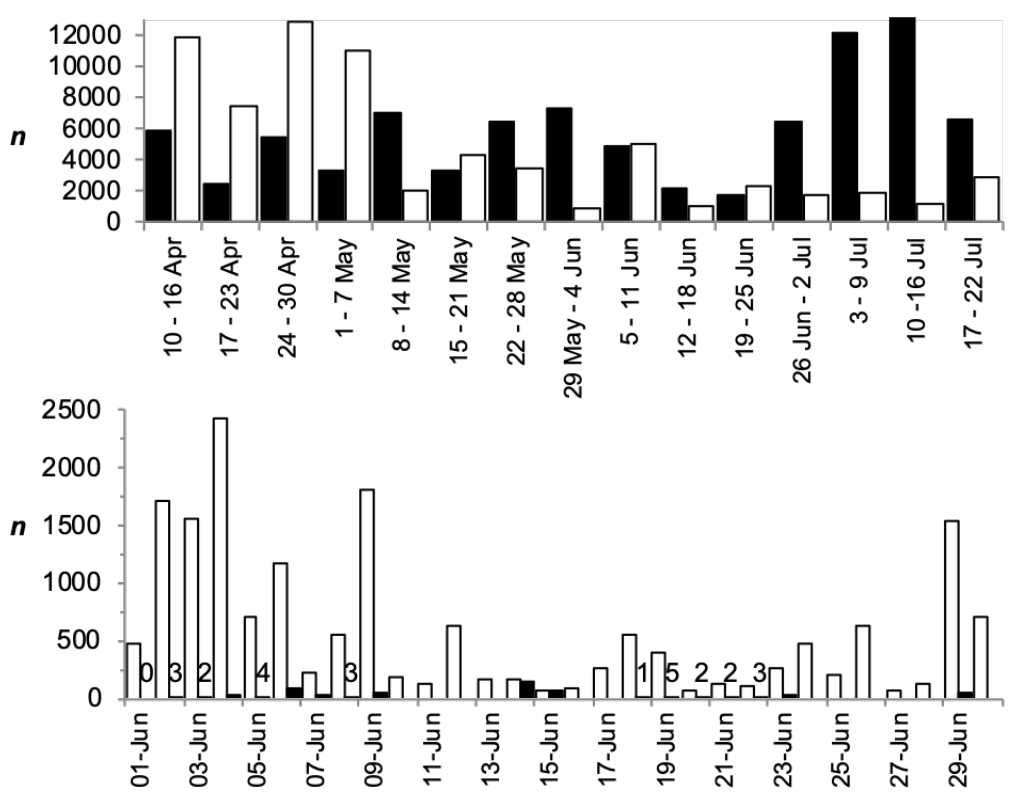

Fig 9 (Top) Weekly estimated catches ( $n$ ) of rainbow smelt (solid bars, $n=93,976$ ) and Atlantic tomcod (open bars, $n=68,212$ ) captured in the Bramber weir during April to July, 2017; and (bottom) estimated and enumerated catches (n) of rainbow smelt at the Bramber weir in June, 2017 during daytime (open bars) and at night (solid bars and numbers). Catches of less than 10 individuals are represented by numbers along the $x$-axis. Day-night catch difference was significant $(\mathrm{P}<\mathbf{0 . 0 5})$.

age- 5 and the longest captured was near the maximum size reported for Maritime coastal waters (356 $\mathrm{mm} \mathrm{L}_{\mathrm{F}}$; Scott and Scott 1988). The $\mathrm{L}_{\mathrm{F}}$ frequency distribution peaked at $100-120 \mathrm{~mm}, 140-150 \mathrm{~mm}$ and 180-200 $\mathrm{mm}$ which represented age-1, age-2 and age-3 smelt, respectively (Scott and Scott 1988)

\section{Gadoids}

A total of nine species of gadoid (cod-like) fishes were captured in the Bramber weir during 2017 (Table 1). Most of the species were captured during the spring, cold water period and occurred rarely. Atlantic cod (six individuals), haddock (six) and pollock (one) represented commercial species captured. The capture of spotted hake (one) and long-fin hake (one) represented off-shore, deep water species and their capture was the first recorded in Minas Basin (Dadswell et al. 1984b; Scott and Scott 1988). Only pollock were recorded during the 2013 weir study (Baker et al. 2014). 


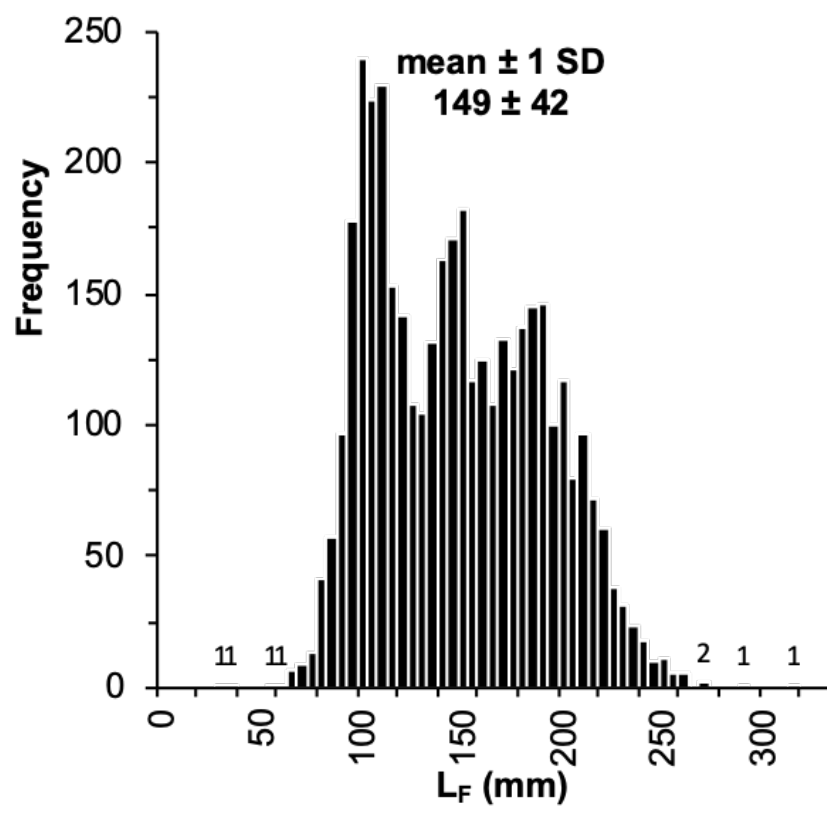

Fig 10 Fork length $(\mathrm{mm})$ frequency histograms of rainbow smelt sampled at the Bramber weir, during April to July, 2017. Unmeasured fork lengths $(n=14)$ were extrapolated based on the following fork to total length relationship $\left(L_{T}=1.0793 L_{F}+3.2131 ; r^{2}=0.99 ; n=1,227\right)$. Lengths are grouped together in $5 \mathrm{~mm}$ bins. Counts of less than 3 individuals per bin are labeled for clarity.

\section{Hakes}

A total of 384 silver hake were captured from April to July. Catches ranged from 1-28 individuals a tide with the largest catches during May and June which was similar to other weir studies (Leim 1924; Dadswell et al. 1984b). Captured silver hake ranged in length from 62-304 $\mathrm{mm} \mathrm{L}_{\mathrm{T}}$.

A total of 7,214 red and white hake were captured during 2017. These two species are difficult to differentiate between and weir identification was probably inaccurate. Correct identification of red and white hake requires examining the gill racker count (Scott and Scott 1988). Most of the small hake would have required the use of a microscope for correct determination which would have resulted in their death. Fish identified as red hake occurred mostly during the spring, cold water period. Catches ranged from 1-25 a tide and size from 107- $248 \mathrm{~mm} \mathrm{~L}_{\mathrm{T}}$. An abundance of smaller hakes largely identified as white hake occurred during July. Catches ranged from 1-1,409 individuals a tide ranging in length from $50-105 \mathrm{~mm} \mathrm{~L}_{\mathrm{T}}$. 


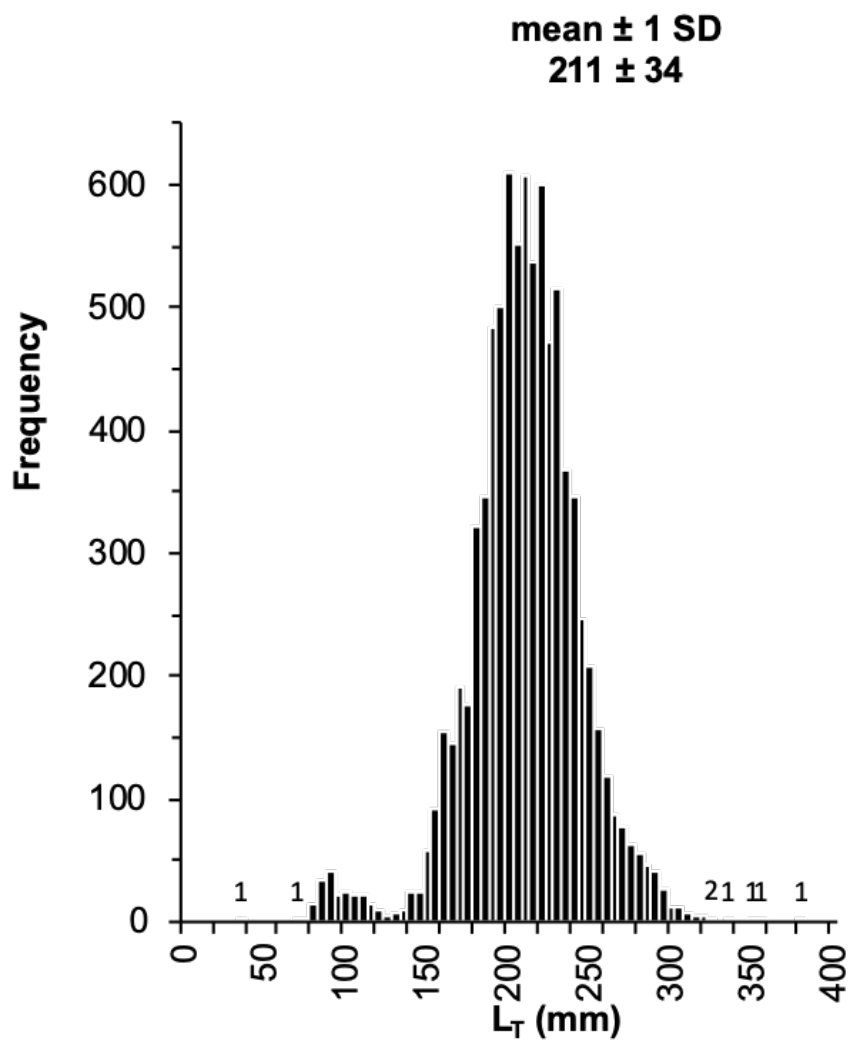

Fig 11 Total length $(\mathrm{mm})$ frequency distribution of Atlantic tomcod sampled at the Bramber weir, from April to July, 2017. Lengths are grouped together in $5 \mathrm{~mm}$ bins. Counts of less than three individuals per bin are labeled for clarity.

Atlantic tomcod The estimated catch of Atlantic tomcod during 2017 was 68,212 or $10.1 \%$ of the total weir catch (Table 1). Weekly estimated catches ranged from several hundred to over 13,000 fish (Fig 9). Tomcod were captured throughout the fishing season but the largest catches were during April to early June.

The length distribution of tomcod was similar throughout the fishing period. Tomcod $\mathrm{L}_{\mathrm{T}}$ ranged from $35-380 \mathrm{~mm}$ and the mean length $\pm 1 \mathrm{SD}$ was $211 \pm 34 \mathrm{~mm} \mathrm{~L}_{\mathrm{T}}$ (Fig 11). These were mostly adult fish of age-2 to age-4 (Dadswell et al. 1984b). Juvenile tomcod (age-0) are pelagic and remain in the water column away from the intertidal zone until autumn (Scott and Scott 1988). 
Tomcod are abundant in the inner Bay of Fundy especially in regions where the water is turbid (Dadswell et al. 1984b). They are an anadromous fish that spawns in freshwater streams during December and January and are often called 'frostfish' because of this behavior (Scott and Scott 1988). Since they are available when other fish are not they are fished during winter by the Mi'kamaq to whom they are known as 'punamuiku'. There is an extremely large run of tomcod in the Shubenacadie River each winter that attracts large numbers of bald eagles (Reid 1982).

\section{Monkfish}

An uncommon species taken at the Bramber weir was the monkfish, a member of the angler or goosefish family (Lophiidae). Only four individuals were captured during 2017 (Table 1). Monkfish mostly prey on flounders and follow them onto the intertidal zone at high tide. They are often stranded in the intertidal tide zone since they are a lay-in-wait predator and the fast moving tide in Minas Basin catches them unawares (Bleakney and MacAllister 1973).

\section{Other Rarely Captured Fishes}

Other fishes that were rare or uncommonly captured in the Bramber weir were mummichog (two individuals), northern pipefish (seven), and cunner (51). All these fishes are much more common in Minas Basin than the weir catches suggest but were poorly represented because of their biology or physical characteristics (Scott and Scott 1988). Mummichog are extremely common in intertidal tide pools in salt marshes and remain close to that habitat (Bleakney and BaileyMeyer 1979). Pipefish have a small diameter body and would pass easily through the weir mesh. Cunner are a species that remains close to rocky shores and wharfs and would rarely move over muddy, intertidal zones (Scott and Scott 1988).

\section{Striped bass}

A total of 1,388 striped bass were captured during 2017 (Table 1). Weekly catches varied from 20-35 fish during April to 70-190 fish during May-July (Fig 12). Largest catches were during May.

Striped bass captured ranged from 7.9 to $93.3 \mathrm{~cm} \mathrm{~L}_{\mathrm{T}}$ and mean $\mathrm{L}_{\mathrm{T}} \pm$ $1 \mathrm{SD}$ was $38.5 \pm 10.8 \mathrm{~cm}$ (Fig 12). The majority of the catch was from 30-40 $\mathrm{cm} \mathrm{L} \mathrm{L}_{\mathrm{T}}$ which represented age-3 and age- 4 fish (Broome 2014). The largest bass were probably more than age-20. The length range 

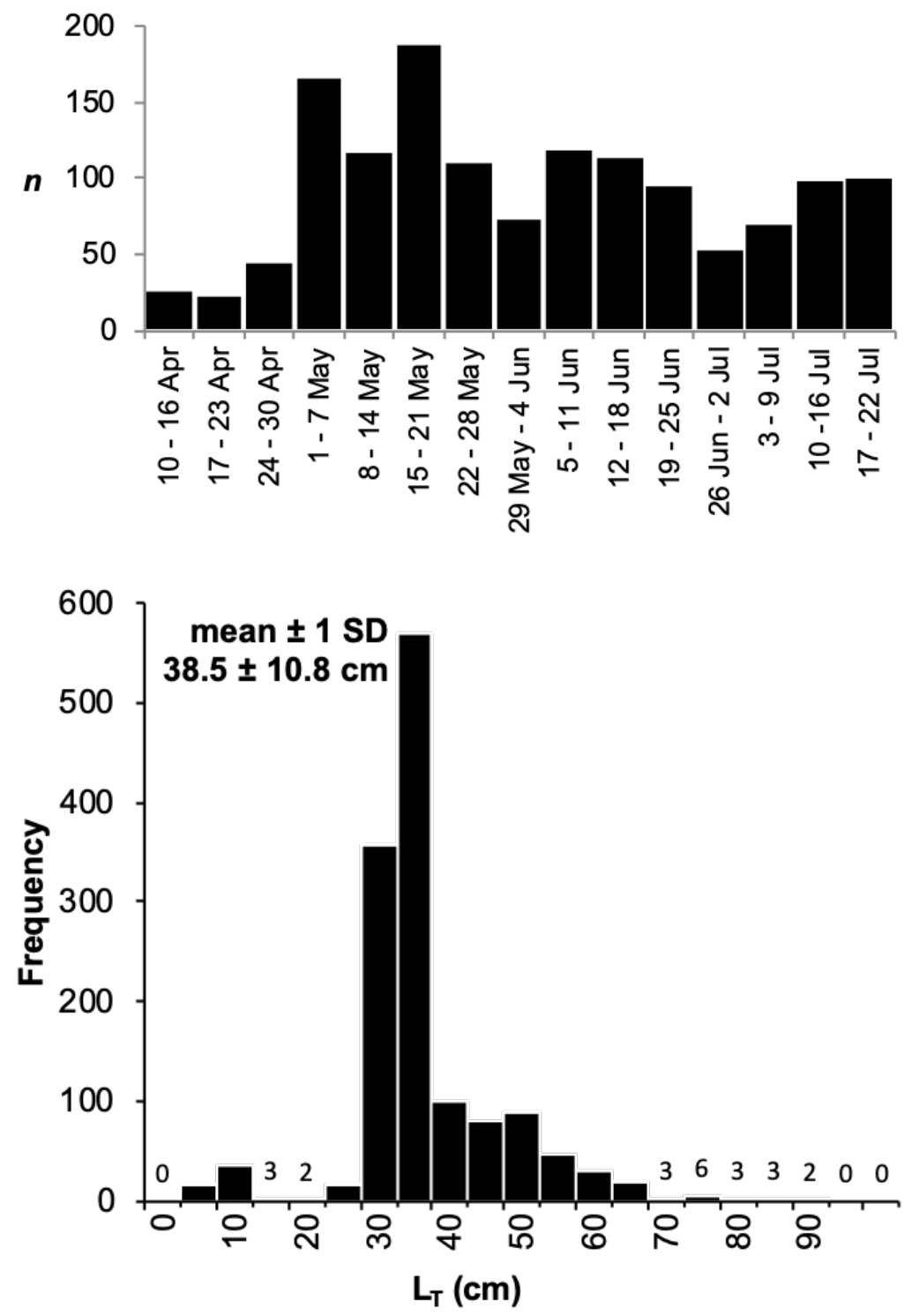

Fig 12 (Top) Weekly catch ( $n$ ) of striped bass from the Bramber weir during April to July, 2017. Total catch was 1,388 fish. (Bottom) Total length $(\mathrm{cm})$ frequency distribution of striped bass captured at the Bramber weir from April to July, 2017. Unmeasured total lengths $(n=4)$ were extrapolated based on the following fork to total length relationship $\left(L_{T}=1.0697 L_{F}+4.3996 ; r_{2}=\right.$ $0.99 ; n=1,381)$. Numbers along of $x$-axis are length groups with less than 10 fish. 
of striped bass captured during 2017 was similar to those captured in the weirs during 2013 (Baker et al. 2014).

Striped bass are an anadromous species that has riverine populations along the east coast of North America (Rulifson and Dadswell 1995). The major spawning population in Minas Basin occurs in the Schubenacadie River (Rulifson and Tull 1998). Most of the striped bass found in Minas Basin are from the local stock which largely remains in inner Bay of Fundy (Broome 2014; Keyser et al. 2016) but migratory bass also pass through each summer. Striped bass tagged in Minas Basin have been recaptured as far south as Virginia (Rulifson et al. 2008).

Striped bass are managed as a sports fishery in Canada and both sport and commercial catches are restricted to one fish a day in excess of $68.5 \mathrm{~cm} \mathrm{~L}_{\mathrm{T}}$ (Broome 2014). A total of 105 of the released bass were tagged with external tags for researchers from Acadia University. Thirty- three of the bass caught had external tags applied in Minas Basin during previous years.

\section{White Perch}

White perch was rarely captured in the weir during 2017. Only 12 were taken (Table 1). White perch were not reported during the 2013 weir study (Baker et al. 2014).

White perch are an estuarine-freshwater fish and rarely move into high salinity habitats (Scott and Scott 1988). The Avon River head pond behind the causeway at Windsor has a large population of white perch which largely remain in the low salinity estuary (D. Porter, pers. obs.).

\section{Silversides}

Silversides are a small, schooling fish species that is important forage for striped bass. They generally remain over sandy and gravely beaches and are abundant in that habitat in Minas Basin (Gilmurry and Daborn 1981). They seldom live past 2 years of age or exceed 200 $\mathrm{mm} \mathrm{L}_{\mathrm{F}}$. A total of 2,063 silversides were captured in the Bramber weir during April-July, 2017. Catches ranged from 1-164 a tide and were almost a daily catch over the entire weir season. Catches were, however, probably not representative of silversides abundance in the region of the weir and larger catches probably occurred when a school was intercepted by the weir. Silversides captured were from $72-127 \mathrm{~mm} \mathrm{~L}_{\mathrm{F}}$. Their small size would allow most to escape through the weir mesh. 


\section{Sculpins}

Three species of sculpin were captured in the Bramber weir, longhorn sculpin, shorthorn sculpin and sea raven. During 2017 a total of 705 longhorn sculpin and 643 sea raven were captured but only four shorthorn sculpin (Table 1). Weekly catches of longhorn sculpin and sea raven occurred throughout the fishing season but were greatest during May and June when 60-80 sculpins were captured each week (Fig 13).

Longhorn sculpin captured during 2017 ranged from 30-398 $\mathrm{mm} \mathrm{L}_{\mathrm{T}}$ (Fig 14) and mean length $\pm 1 \mathrm{SD}$ of was $261 \pm 60 \mathrm{~mm} \mathrm{~L}_{\mathrm{T}}$. Sea raven captured during 2017 ranged from 102-502 $\mathrm{mm} \mathrm{L}_{\mathrm{T}}$ (Fig 14) and mean length $\pm 1 \mathrm{SD}$ was $336 \pm 55 \mathrm{~mm} \mathrm{~L}_{\mathrm{T}}$. Most of the sculpin captured were adults of 200-500 $\mathrm{mm} \mathrm{L}_{\mathrm{T}}$ (Scott and Scott 1988).

\section{Summer-warm Fishes}

Each year Minas Basin weirs capture a small number of rare, summer-warm species (Dadswell et al. 1984b). Only striped sea robin (one) and summer flounder (two) were observed during 2017 (Table 1). Striped searobin is an occasional catch in Minas Basin (Dadswell and Rulifson, in press). Summer flounder is a southern species rarely captured even in the Bay of Fundy (Scott and Scott 1988). In past years, scup, various drum species and black sea bass have been taken in the weirs (Dadswell and Rulifson, in press). Bluefish (Pomatomus saltatrix) were captured at the Bramber weir during 2013 (Baker et al. 2014) but not during 2017.

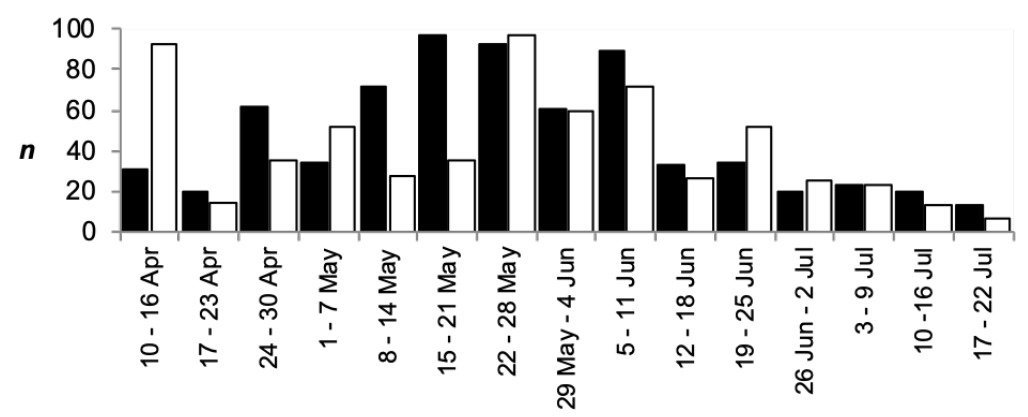

Fig 13 Weekly catches ( $n$ ) of longhorn sculpin (solid bars, $n=701$ ) and sea raven (open bars, $n=634$ ) captured in the Bramber weir during April to July, 2017. 


\section{Butterfish}

On the other hand, a number of other summer visitors are a yearly event and are often abundant. During 2017 a total of 536 butterfish were captured in the Bramber weir (Table 1). Catches were greatest during June (Fig 15). Butterfish are common in the pelagic zone of Minas Basin (Dadswell et al. 1984b) and catches in the Bramber weir
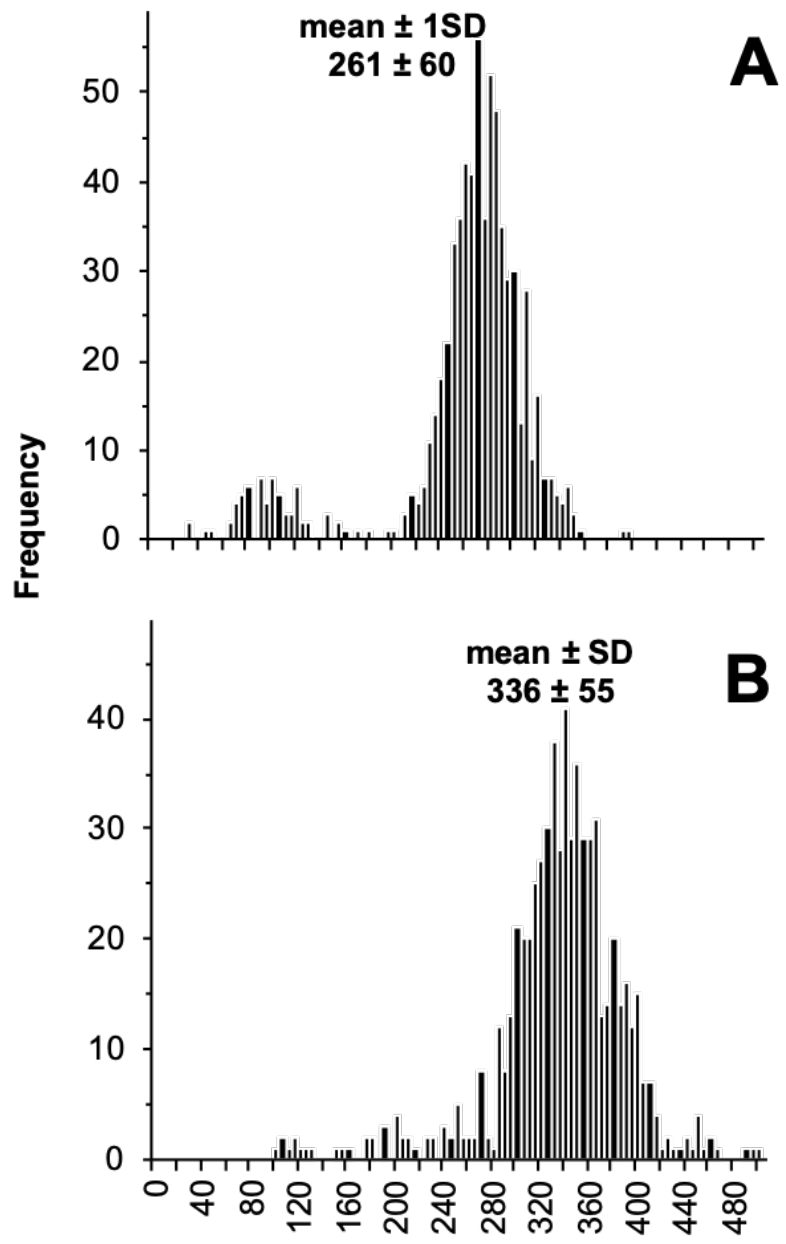

\section{$\mathrm{L}_{\mathrm{T}}(\mathbf{m m})$}

Fig 14 Total length $(\mathrm{mm})$ frequency distribution of A) longhorn sculpin and B) sea raven captured in the Bramber weir during April to July, 2017. Lengths are grouped in $5 \mathrm{~mm}$ bins. 
probably underestimated their abundance during 2017, since butterfish are a small fish and many could have escaped through the weir mesh. The catch during 2017 included individuals from 52-150 $\mathrm{mm} \mathrm{L}_{\mathrm{F}}$.

\section{Atlantic mackerel}

The Atlantic mackerel run in Minas Basin occurs during early to mid-summer. Mackerel avoid the turbid water portion of Minas Basin (Cobequid Bay and the Southern Bight; Fig 1) and are only captured at the Bramber weir during periods of neap tides and light winds when the water is clear (D. Porter, pers. obs.). During 2017, a total of 1,820 mackerel were captured during June 17-22 (Fig 15). These fish measured $233-289 \mathrm{~mm} \mathrm{~L}_{\mathrm{F}}$, which is the average size for age-2 'tinker' mackerel (Scott and Scott 1988).

\section{Flounders}

Flounder were a daily and abundant catch during 2017. Total estimated catches for smooth, winter and windowpane flounder were 5,841, 24,214 and 18,860 respectively (Table 1). Weekly catches (Fig 15) of smooth flounder were greatest during April-May (1001800), winter flounder from May to June (1000-4000) and windowpane from May-July (500-3500). Halibut is a cold water species and only two individuals were captured during early spring.

Captured smooth flounder ranged from $35-395 \mathrm{~mm} \mathrm{~L}_{\mathrm{T}}$ (mean \pm 1 $\left.\mathrm{SD}, 199 \pm 54 \mathrm{~mm} \mathrm{~L}_{\mathrm{T}}\right)$, winter flounder from $47-420 \mathrm{~mm} \mathrm{~L}_{\mathrm{T}}($ mean \pm $1 \mathrm{SD}, 226 \pm 78 \mathrm{~mm} \mathrm{~L}_{\mathrm{T}}$ ) and windowpane from $50-393 \mathrm{~mm} \mathrm{~L}_{\mathrm{T}}$ (mean $\pm 1 \mathrm{SD}, 217 \pm 82 \mathrm{~mm} \mathrm{~L}_{\mathrm{T}}$; Fig 16).

Flounder is harvested in Minas Basin by both the weir and trawler fisheries (Wehrell 2005; Baker et al. 2014). Smooth and windowpane flounder are year around residents of Minas Basin (Bleakney and McAllister 1973) but winter flounder migrate through Minas Basin each year, arriving in April-May to spawn and departing during August-September for offshore waters (McCracken 1963).

\section{CHARACTERISTICS OF CAPTURED INVERTEBRATES}

Data collected from captured invertebrates included species and number caught. A total of 13 larger and/or abundant species were identified (Table 2). Lady crab was the most abundant invertebrate captured and represented $75.6 \%$ of the catch. They began appearing 

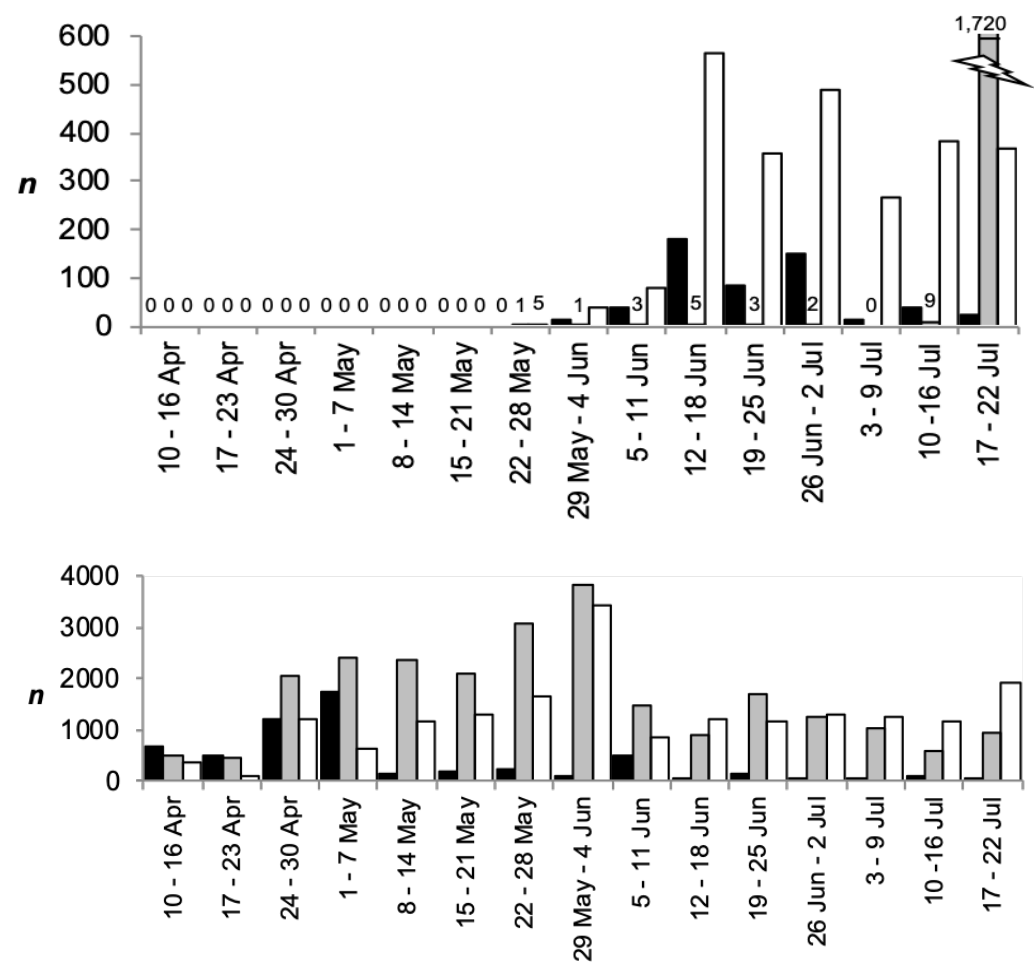

Fig 15 (Top) Weekly catch (n) of summer visitors to Minas Basin: butterfish (solid bars, $n=536$ ), Atlantic mackerel (shaded bars, $n=1,820$ ) and longfin squid (open bars, $n=2,560$ ), captured at the Bramber weir from April to July, 2017. Weekly catches of less than ten individuals are shown with numbers. The weekly catch of mackerel during 17-22 July is denoted with a number and broken bar to indicate the catch is above vertical axis numbering. (Bottom) Weekly estimated catches ( $n$ ) of flounders captured in the Bramber weir during April to July, 2017. Total estimated catches were winter flounder (shaded bars, $n=\mathbf{2 4 , 2 1 4}$ ), smooth flounder (solid bars, $n=5,841$ ) and windowpane flounder (open bars, $n=18,860$ ).

in the catch during mid-May (5-10 each tide) but were most abundant during mid-June to late July (100- 1,000 each tide).

\section{Longfin squid}

Long-fin squid was the only invertebrate species taken in the commercial catch at the Bramber weir. Squid are used by anglers for striped bass fishing and are eagerly sought out from the weir fishers. Long-fin squid are a pelagic species which winters off Long Island, USA and migrates north to Canada (Black et al. 1987). There 

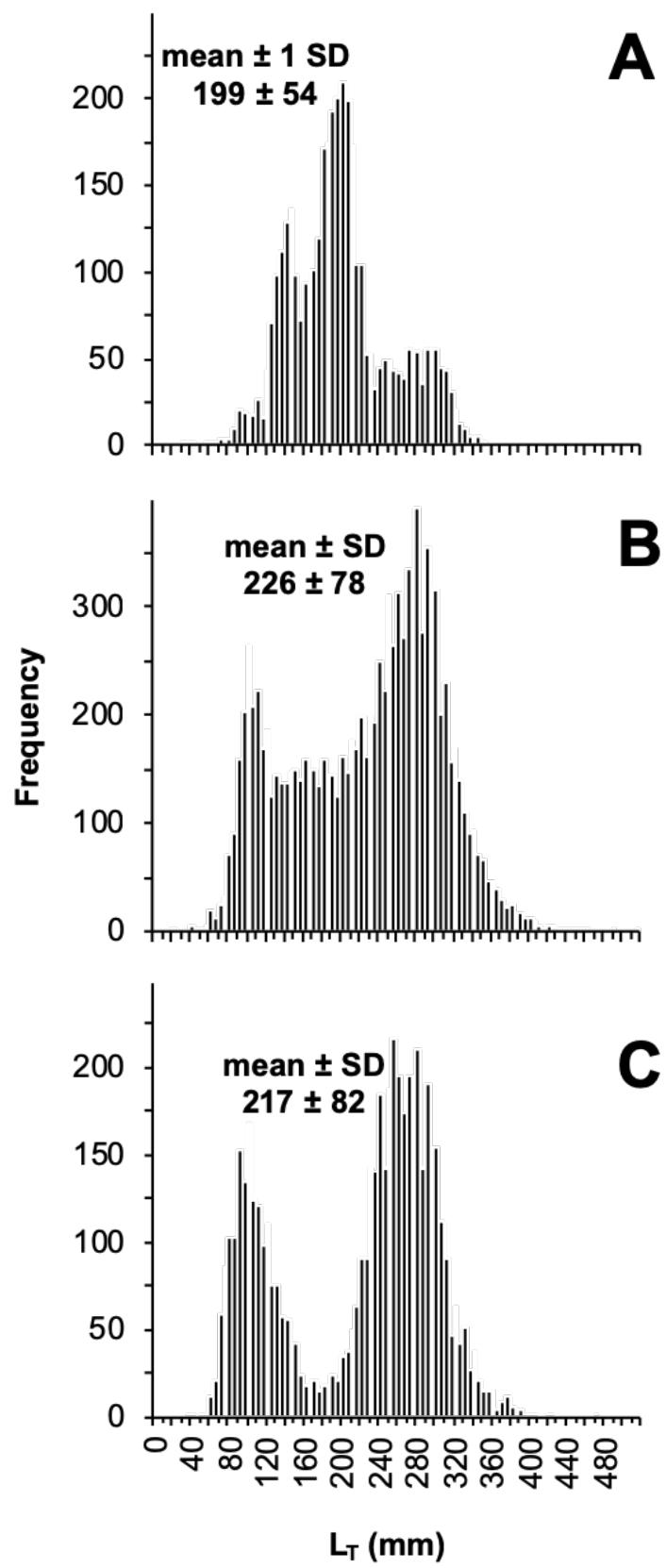

Fig 16 Total length $(\mathrm{mm})$ frequency distributions of A) smooth flounder, B) winter flounder and $C$ ) windowpane flounder captured in the Bramber weir during April to July, 2017 (lengths in $5 \mathrm{~mm}$ bins). 
is a stock that spawns in Minas Basin each summer from July to September (Dadswell, per.observ.). A total of 2,560 squid were captured in the Bramber weir during 2017 (Table 1). Catches began in late May and were highest during June to July when weekly catches were from 300-500 individuals (Fig 15).

Squid grow very rapidly but only live for one year (Black et al. 1987). After spawning the adults die. Young are born from July to September in Minas Basin and return as adults the following summer. A total of 1459 squid were sampled which ranged in total length from $95-640 \mathrm{~mm}$. The catch was a mixture of age- 0 and age- 1 individuals.

\section{CONCLUSIONS}

The Bramber weir is one of six active weirs still operating annually in Minas Basin. There is one at Parrsboro, two at Five Islands, two at Economy and the Bramber weir on the Avon estuary (Fig 1). More weir licenses exist in Minas Basin but are not active every year.

The diversity of the fish catch (45 species) at Bramber during 2017 was similar to that observed by Leim (1924) and Dadswell et al. (1984b) at weirs along the north shore of Minas Basin during the 1920's and 1980's (44 species) and nearly twice as many as were recognized in 2013 during the FORCE study (28 species; Baker et al. 2014). Total known diversity of fishes occurring in Minas Basin during the last four decades is in the range of 75-80 species (Dadswell and Rulifson, in press). Fishes found in Minas Basin that were not captured at Bramber during 2017 included large sharks (great white, sand tiger, porbeagle) and some rare summer-warm migrants including scup, drums, bluefish, tautog, four-spot flounder and ocean sunfish. All of these species have been rare catches in the past. We know that a great white shark was near the Bramber weir during 2017 based on acoustic tag receptions (D. Porter, pers. comm.) but thankfully it was not captured since capture means the difficult process of removing it safely from the weir following the protocol established by DFO.

Abundance and size structure of fishes in the Bramber weir catch during 2017 was comparable to weir studies in the past (Liem 1924; Dadswell et al. 1984b; Baker et al. 2014) except the number of fish measured far exceeded past efforts. The 2017 study measured 57,950 fishes compared to approximately 8300 measured by the FORCE 2013 study (Baker et al. 2014) In all previously studies, the 
dominant catch species were gaspereau, Atlantic herring, American shad, skates, striped bass, mackerel and the flounders. Spiny dogfish shark were more abundant in the 1980 weirs catches because of the large increase in their stock size during 1970-1990 (Campana et al. 2008). The abundance and size structure of skates was similar to previous surveys conducted at the Bramber weir from 2012-2014 (Baker et al. 2014; Whidden 2015). Atlantic sturgeon were less abundant in past weir studies (Liem 1924; Dadswell et al. 1984b) largely because their stocks were formerly depleted by overexploitation and pollution (Dadswell 2006), but they are now recovering and annual catches in weirs have increased (Baker et al. 2014; Dadswell et al. 2016).

The abundance and size structure of gaspereau and striped bass in weir catches during the 1980's and during 2013 was comparable to the 2017 Bramber catch (Rulifson et al. 1987, 2008; Baker et al. 2014). Tomcod abundance and size structure was similar to a population sampled on the intertidal zone in Cumberland Basin, inner Bay of Fundy during 1979 (Dadswell et al.1984b) and those caught at the Bramber weir during 2013 (Baker et al. 2014). The abundance and size structure of winter flounder collected in a Minas Basin trawl catch survey during 2004 (Wehrell 2005) and weir surveys during 2013 (Baker et al. 2014) were similar to the 2017 Bramber weir catch. Individual catches/tide and size structure of Atlantic herring, rainbow smelt, longhorn sculpin, sea raven, smooth and windowpane flounders during 2017 were similar to catches of these species during 2013 at the Bramber weir (Baker et al. 2014).

In conclusion we propose that the Bramber weir catch during 2017 met the requirements set out by DFO for weirs to be a useful tool in gathering comprehensive baseline information to monitor diversity, seasonal abundance and size structure of fishes in Minas Basin. The information on diversity and abundance will be useful for future comparisons if there are changes in these characteristics of Minas Basin fishes caused either by tidal power development impact or exploitation. Also, the detailed length structure provided for each species will provide sufficient data for significant statistical comparisons in the future if the size structure of individual fish species is altered by propeller turbine mortality removing larger individuals (Dadswell et al. 2018) or overexploitation. All these comparisons will be important for assessing any future impact of tidal energy development in the inner Bay of Fundy. 
Acknowledgements We thank the science students and weir tenders that made the collection and analysis of data from the Bramber weir during 2017 possible. The science group included; Carrie Wood, Laura Logan-Chesney, Mathieu Gregoire, Trissa Dunham, and Lita O'Halloran. Weir tenders were; Hunter Porter, Nick Hirtle, Braydon Bartlett, Jack Sheehan, Jonny Weatherbee, Zach MacDonald and Brian Macumber. Funding for the study was provided by Big Moon Power Canada, Halifax, NS.

\section{REFERENCES}

Baker, M., Reed, M. \& Redden, A.M. (2014). Temporal patterns in Minas Basin in intertidal weir catches and presence of harbour porpoise during April-August 2013. Acadia Centre for Estuarine Research Tech. Rep. 120.

Black, G.A.D., Rowell, T.W. \& Dawe, E.G. (1987). Atlas of the biology and distribution of the squids Illex illecebrosus and Loligo pealei in the northwest Atlantic. Canadian Special Publication, Fisheries and Aquatic Sciences 100.

Bleakney,J.S. \& McAllister, D.E. (1973). Fishes stranded during extreme low tides in Minas Basin, Nova Scotia. Canadian Field Naturalist 87:371-376.

Bleakney, J.S. \& Bailey-Meyer, K. (1979). Observations on salt-marsh tide pools, Minas Basin, Nova Scotia. Proceedings of the Nova Scotian Institute of Science 29: 353-371.

Bradford, R.G. \& Iles, T.D. (1993). Retention of herring Clupea harengus larvae inside Minas Basin, inner Bay of Fundy. Canadian Journal of Zoology 71: 56-63.

Broome, J.E. (2014). Population characteristics of striped bass (Morone saxatilis Walbaum, 1792) in Minas Basin and patterns of acoustically detected movements within Minas Passage. M.Sc. Thesis, Acadia University, Wolfville, NS.

Campana, S.E., Gibson, A.J.F., Marks, L., Joyce, W., Rulifson, R.A. \& Dadswell, M.J. (2008). Stock structure, life history, fishery and abundance for spiny dogfish (Squalus acanthias) in Atlantic Canada. Canadian Science Advisory Secretariat, Research Document 2007/2008.

Dadswell, M.J. (2006). A review of the status of Atlantic sturgeon, Acipenser oxyrinchus Mitchill, 1814 in Canada, with comparisons to Europe and the United States. Fisheries 31: 218-229.

Dadswell, M.J. \& Rulifson, R.A. (2020). The fishes and fisheries of Minas Basin and Minas Passage, Nova Scotia and their risk from tidal power development. Proceedings of the Nova Scotian Institute of Science 51(1), in prep. 
Dadswell, M.J., Melvin, G.D., Williams, P.J. and Brown, G.S. (1984a). Possible impact of large-scale tidal power developments in the upper Bay of Fundy on certain migratory fish stocks of the Northwest Atlantic. Canadian Technical Report, Fisheries and Aquatic Science 1256: 577-599.

Dadswell, M.J., Bradford, R, the late Leim, A.H., Scarratt, D.J., Melvin, G.D. \& Appy, R.G. (1984b). A review of research on fishes and fisheries in the Bay of Fundy between 1976 and 1983 with particular attention to its upper reaches. Canadian Technical Report, Fisheries and Aquatic Science 1256: 163-294.

Dadswell, M.J., Melvin, G.D., Williams, P.J. \& Themelis. D.E. (1987). Influence of origin, life history and chance on the Atlantic coast migration of American shad. American Fisheries Society Symposium 1: 313-330.

Dadswell, M.J., Wehrell, S.A., Spares A.D., McLean, M.F., Beardsall, J.W., Logan- Chesney, L.M., Nau, G., Redden, A.M. \& Stokesbury M.J.W.(2016). The annual marine feeding aggregation of Atlantic sturgeon Acipenser oxyrinchus in the inner Bay of Fundy: population charactersitics and movements. Journal of Fisheries Biology 89: 2107-2132.

Dadswell, M.J., Ceapa, C., Spares, A.D., Stewart, N.D., Curry, A., Bradford, R., \& Stokesbury, M.J.W. (2017). Population characteristics of adult Atlantic sturgeon captured by the commercial fishery in the Saint John River, New Brunswick, Canada. Transactions of the American Fisheries Society 146: 318-330.

Dadswell, M.J., Spares, A.D., McLean, M.F., Harris, P. J. \& Rulifson, R.A. (2018). Long- term impact of a tidal, hydroelectric propeller turbine on the populations of three anadromous fish species. Journal of Fisheries Biology 93: 192-206.

DFO. (Department of Fisheries and Oceans). (2016). Review of the environmental effects monitoring program for the Fundy tidal energy project. Canadian Science Advisory Secretariat, Research Document 2016/022.

Gibson, A.J.F. \& Dabor, G.R. (1997). The 1997 alewife spawning migration in the Gaspereau River, Nova Scotia. Acadia Center for Estuarine Research Tech. Rep. 45.

Gilmurray, M.C. \& Daborn, G.R. (1981). Feeding relations of the Atlantic silversides Menidia menidia in the Minas Basin, Bay of Fundy. Marine Ecology-Progress Series 6: 231-235.

Gordon, J. (1993). The woven weirs of Minas. Nova Scotia Department of Education, Curatorial Report 73.

Keyser, F.M., Broome, J.E., Bradford, R.G., Sanderson, B. \& Redden, A.M. (2016). Winter presence and temperature related diel migration of striped bass Morone saxatilis in an extreme high flow passage in the Bay of Fundy. Canadian Technical Report, Fisheries and Aquatic Science 73: 1777-1786.

Leim, A.H. (1924). The life history of the shad $\{$ Alosa sapidissima (Wilson) $\}$ with special reference to the factors limiting its abundance. Contributions to Canadian Biology 2: 163-284. 
McCracken, F.D. (1963). Seasonal movements of the winter flounder Pseudopleuronectes americanus (Walbaum) on the Atlantic coast. Journal of the Fisheries Research Board of Canada 20: 551-586.

McLean, M.F., Dadswell, M.J. \& Stokesbury, M.J.W. (2013). Feeding ecology of Atlantic sturgeon, Acipenser oxyrinchus oxyrinchus Mitchill, 1815 on the infauna of intertidal mudflats of Minas Basin, Bay of Fundy. Journal of Applied Ichthyology 29: 503-509.

Moore, T.M. (1998). Population characteristics of spiny dogfish, Squalus acanthias Linnaeus, 1758, from geographically distinct locations in Atlantic Canada during the summer and fall of 1996. M.Sc. Thesis, Acadia University, Wolfville, Nova Scotia.

Parker, M., Westhead, M., \& Service, A. (2007). Ecosystem overview report for the Minas Basin, Nova Scotia. Fisheries and Oceans Canada/ Oceans and Habitat Report 2007-05.

Perley, M.H. (1852). Reports on the sea and river fisheries of New Brunswick, $2^{\text {nd }}$ ed. Queens Printer, Fredericton, N.B.

Scott, W.B. \& Scott, M.G. (1988). Atlantic fishes of Canada. Canadian Bulletin of Fisheries and Aquatic Sciences 219.

Reid, P.R. (1982). Aspects of the winter ecology and behavior of bald eagles (Haliaectus leucocephalus alaseanus Townsend) on the Shubenacadie River, Nova Scotia. M.Sc. Thesis, Acadia University, Wolfville, NS.

Rulifson, R.A. \& Dadswell, M.J. (1995). Life history and population characteristics of striped bass in Atlantic Canada. Transactions of the American Fisheries Society 124: 477-507.

Rulifson, R.A. \& Tull, K.A. (1998). Striped bass spawning in a tidal bore river: the Shubenacadie estuary, Atlantic Canada. Transactions of the American Fisheries Society 128: 613-624.

Rulifson, R.A. McKenna, S.A. \& Gallager, M.L. (1987). Tagging studies of striped bass and river herring in the upper Bay of Fundy, Nova Scotia. East Carolina University, Institute of Coastal Marine Research Tech. Rept. 82-02.

Rulifson, R.A., McKenna, S.A. \& Dadswell, M.J. (2008). Use of intertidal habitat, population characteristics, movement and exploitation of striped bass in Minas Basin, Bay of Fundy, Canada. Transactions of the American Fisheries Society 137: 23-32.

Sanderson, B.G. \& Redden, A.M. (2015). Perspective on the risk that sediment-laden ice poses to in-stream tidal turbines in Minas Passage, Bay of Fundy. International Journal of Marine Energy 10: 52-69.

Stone, H.H. (1985). Composition, morphological characteristics and feeding ecology of alewives (Alosa pseudoharengus) and blueback herring (A. aestivalis) (Pisces: Clupeidae) in Minas Basin. M.Sc. Thesis, Acadia University, Wolfville, Nova Scotia.

Wehrell, S. (2005). A survey of the groundfish caught by the summer trawl fishery in Minas Basin and Scots Bay. Honours Thesis, Dept. of Biology, Acadia University, Wolfville, NS. 
Whidden, J.A. (2015). Population demographics and species identification of two at-risk skates, little skate Leucoraja erinacea and winter skate Leucoraja ocellata in Minas Basin, Bay of Fundy. M.Sc. Thesis, Acadia University, Wolfville, NS.

Wirgin, I., Maceda, L., Waldman, J.R., Wehrell, S., Dadswell, M.J. \& King, T. (2012). Stock origin of migratory Atlantic sturgeon in Minas Basin, inner Bay of Fundy, Canada, determined by microsatellite and mitochondrial DNA analyses. Transactions of the American Fisheries Society 141: 1389-1398. 